University of Nebraska - Lincoln DigitalCommons@University of Nebraska - Lincoln

$9-2003$

EFFECTS OF MANAGEMENT PRACTICES ON GRASSLAND BIRDS: GREATER PRAIRIECHICKEN

W.D. Svedarsky

J. E. Toepfer

R. L. Westemeier

R.J. Robel

Follow this and additional works at: http://digitalcommons.unl.edu/empgb

Part of the Ornithology Commons, Plant Sciences Commons, and the Terrestrial and Aquatic Ecology Commons

This Article is brought to you for free and open access by the US Geological Survey at DigitalCommons@University of Nebraska - Lincoln. It has been accepted for inclusion in Effects of Management Practices on Grassland Birds by an authorized administrator of DigitalCommons@University of Nebraska - Lincoln. 


\section{EFFECTS OF MANAGEMENT PRACTICES ON GRASSLAND BIRDS:}

\section{GREATER PRAIRIE-CHICKEN}

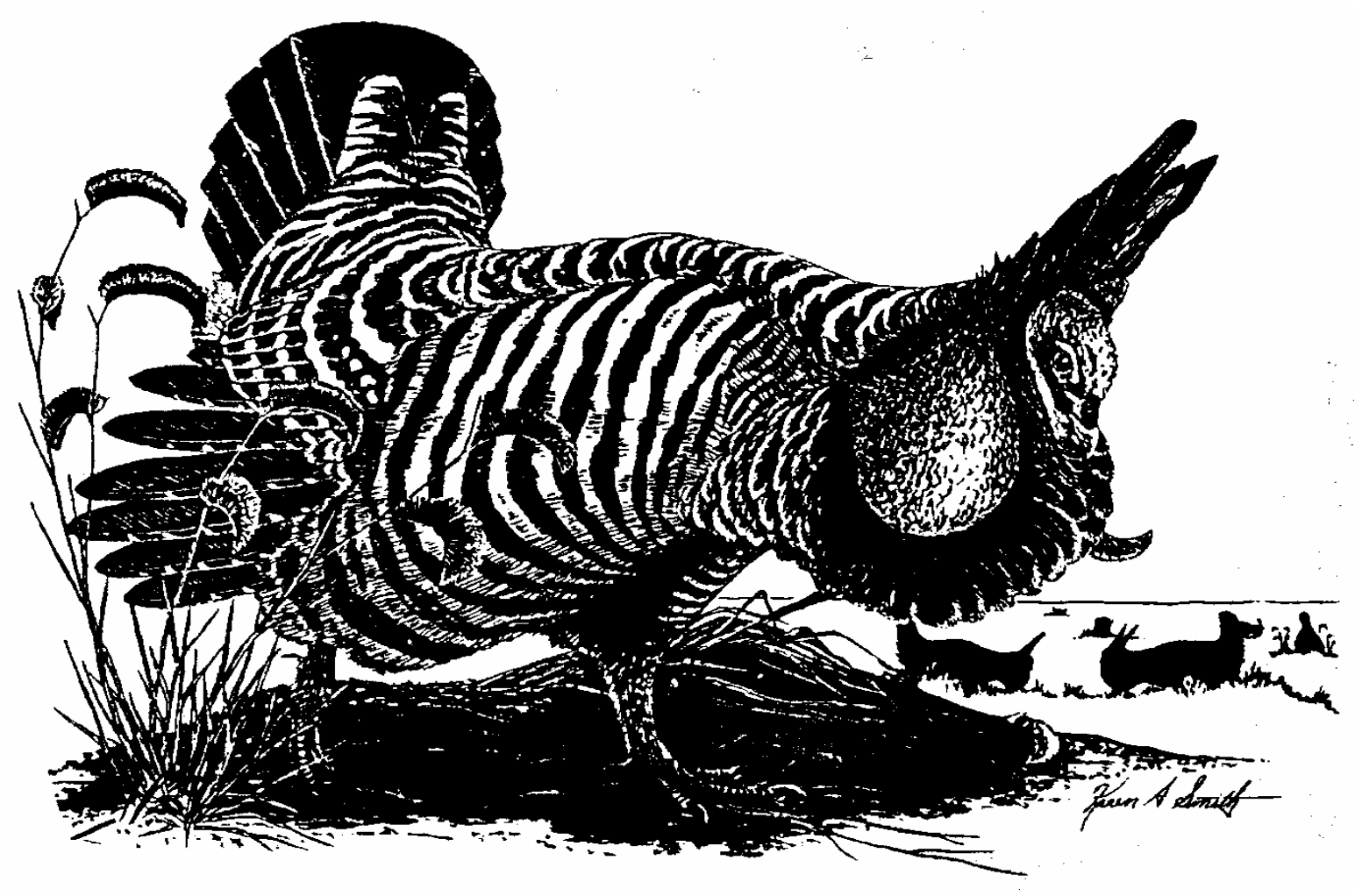

Grasslands Ecosystem Initiative

Northern Prairie Wildlife Research Center

U.S. Geological Survey

Jamestown, North Dakota 58401 
This report is one in a series of literature syntheses on North American grassland birds. The need for these reports was identified by the Prairie Pothole Joint Venture (PPJV), a part of the North American Waterfowl Management Plan. The PPJV recently adopted a new goal, to stabilize or increase populations of declining grassland- and wetland-associated wildlife species in the Prairie Pothole Region. To further that objective, it is essential to understand the habitat needs of birds other than waterfowl, and how management practices affect their habitats. The focus of these reports is on management of breeding habitat, particularly in the northern Great Plains.

Suggested citation:

Svedarsky, W. D., J. E. Toepfer, R. L. Westemeier, and R. J. Robel. 2003. Effects of management practices on grassland birds: Greater Prairie-Chicken. Northern Prairie Wildlife Research Center, Jamestown, ND. 42 pages.

Species for which syntheses are available or are in preparation:

American Bittern

Mountain Plover

Marbled Godwit

Long-billed Curlew

Willet

Wilson's Phalarope

Upland Sandpiper

Greater Prairie-Chicken

Lesser Prairie-Chicken

Greater Sage-Grouse

Northern Harrier

Swainson's Hawk

Ferruginous Hawk

Golden Eagle

Prairie Falcon

Merlin

Short-eared Owl

Burrowing Owl

Horned Lark

Sedge Wren

Loggerhead Shrike
Sprague's Pipit

Grasshopper Sparrow

Baird's Sparrow

Henslow's Sparrow

Le Conte's Sparrow

Nelson's Sharp-tailed Sparrow

Vesper Sparrow

Savannah Sparrow

Lark Sparrow

Field Sparrow

Brewer's Sparrow

Clay-colored Sparrow

Chestnut-collared Longspur

McCown's Longspur

Dickcissel

Lark Bunting

Bobolink

Eastern Meadowlark

Western Meadowlark

Brown-headed Cowbird 


\section{EFFECTS OF MANAGEMENT PRACTICES ON GRASSLAND BIRDS: GREATER PRAIRIE-CHICKEN}

W. D. Svedarsky, J. E. Toepfer, R. L. Westemeier, and R. J. Robel

Series Coordinator: Douglas H. Johnson

Series Assistant Coordinator: Lawrence D. Igl, Jill A. Dechant

Range Map: W. D. Svedarsky

Cover Art: Karen A. Smith

Major Funding: Prairie Pothole Joint Venture, U.S. Fish and Wildlife Service U.S. Geological Survey

Funding also provided by: U.S. Forest Service

The Nature Conservancy

\section{Collaborators:}

Louis B. Best, Iowa State University

Carl E. Bock, University of Colorado

Brenda C. Dale, Canadian Wildlife Service

Stephen K. Davis, Saskatchewan Wetland Conservation Corporation

James J. Dinsmore, Iowa State University

James K. Herkert, Illinois Endangered Species Protection Board

Fritz L. Knopf, Midcontinent Ecological Science Center

Rolf R. Koford, Iowa Cooperative Fish and Wildlife Research Unit

David R. C. Prescott, Alberta NAWMP Centre

Mark R. Ryan, University of Missouri

David W. Sample, Wisconsin Department of Natural Resources

David A. Swanson, Ohio Division of Wildlife

Peter D. Vickery, Massachusetts Audubon Society

John L. Zimmerman (retired), Kansas State University 


\section{ORGANIZATION AND FEATURES OF THIS SPECIES ACCOUNT}

Information on the habitat requirements and effects of habitat management on grassland birds were summarized from information in more than 5,500 published and unpublished papers. A range map is provided to indicate the breeding distribution of Greater Prairie-Chicken in the United States and southern Canada. Although birds frequently are observed outside the breeding range indicated, the maps are intended to show areas where managers might concentrate their attention. It may be ineffectual to manage habitat at a site for a species that rarely occurs in an area. The species account begins with a brief capsule statement, which provides the fundamental components or keys to management for the species. A section on breeding range outlines the current breeding distribution of the species in North America. The suitable habitat section describes the breeding habitat and occasionally microhabitat characteristics of the species, especially those habitats that occur in the Great Plains. Details on habitat and microhabitat requirements often provide clues to how a species will respond to a particular management practice. A table near the end of the account complements the section on suitable habitat, and lists the specific habitat characteristics for the species by individual studies. A special section on prey habitat is included for those predatory species that have more specific prey requirements. The area requirements section provides details on territory and home range sizes, minimum area requirements, and the effects of patch size, edges, and other landscape and habitat features on abundance and productivity. It may be futile to manage a small block of suitable habitat for a species that has minimum area requirements that are larger than the area being managed. The section on breeding-season phenology and site fidelity includes details on spring arrival and fall departure for migratory populations in the Great Plains, peak breeding periods, the tendency to renest after nest failure or success, and the propensity to return to a previous breeding site. The duration and timing of breeding varies among regions and years. Species' response to management summarizes the current knowledge and major findings in the literature on the effects of different management practices on the species. The section on management recommendations complements the previous section and summarizes specific recommendations for habitat management provided in the literature. If management recommendations differ in different portions of the species' breeding range, recommendations are given separately by region. The literature cited contains references to published and unpublished literature on the management effects and habitat requirements of the species. This section is not meant to be a complete bibliography; a searchable, annotated bibliography of published and unpublished papers dealing with habitat needs of grassland birds and their responses to habitat management is posted at the Web site mentioned below.

Parts of the Greater Prairie-Chicken report were modified from Svedarsky and Van Amburg (1996). This report has been downloaded from the Northern Prairie Wildlife Research Center World-Wide Web site, www.npwrc.usgs.gov/resource/literatr/grasbird/grasbird.htm. Please direct comments and suggestions to Douglas H. Johnson, Northern Prairie Wildlife Research Center, U.S. Geological Survey, 8711 37th Street SE, Jamestown, North Dakota 58401; telephone: 701-253-5539; fax: 701-253-5553; e-mail: Douglas_H_Johnson@usgs.gov. 


\section{GREATER PRAIRIE-CHICKEN}

\section{(Tympanuchus cupido pinnatus)}

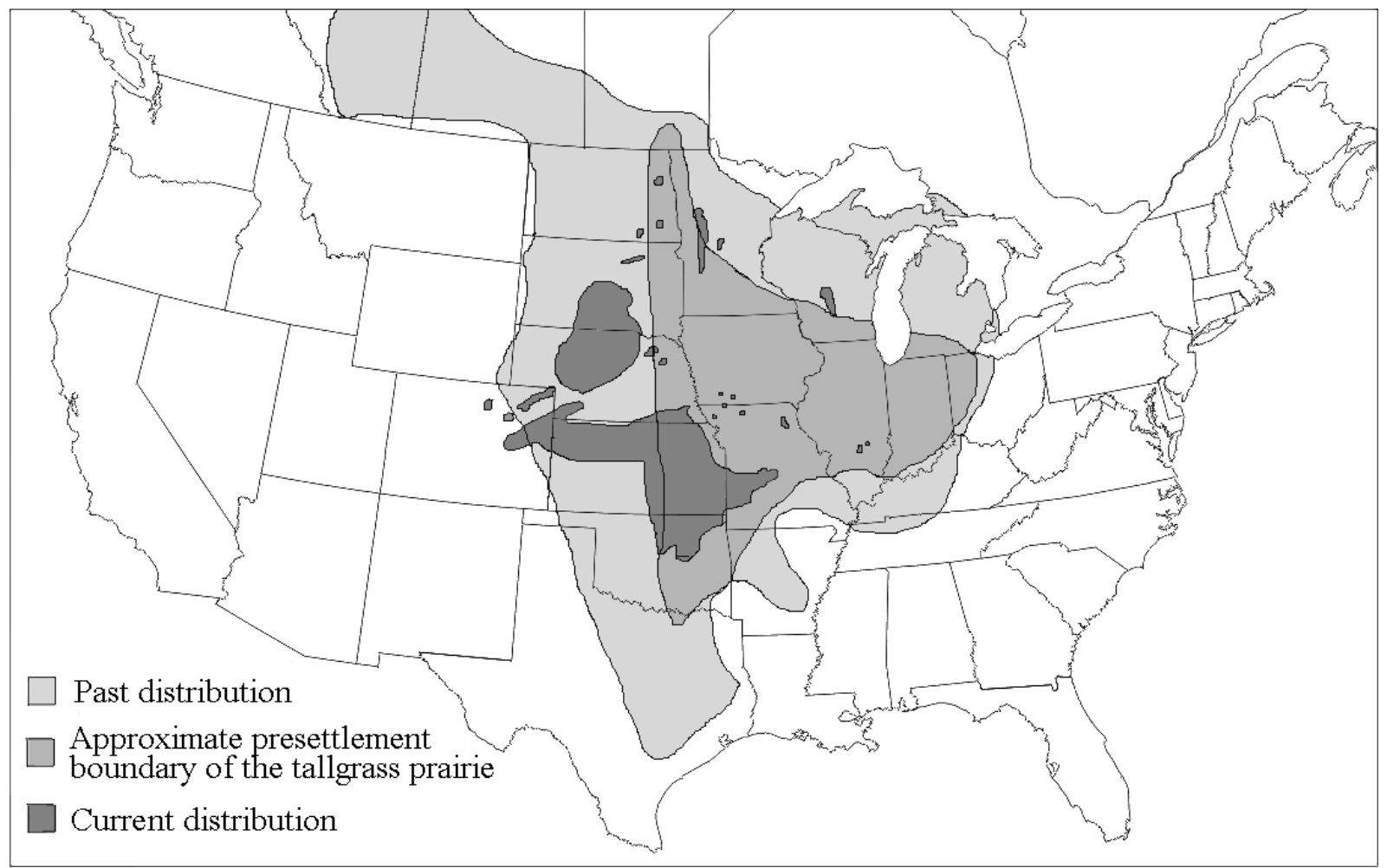

Figure. Breeding distribution of Greater Prairie-Chicken in the United States and southern Canada. Past (dashed line, adapted from Schroeder and Robb 1993) and current (solid areas, adapted from Westemeier and Gough 1999), distribution of the Greater Prairie-Chicken in North America. Solid line delineates the approximate presettlement boundary of the tallgrass portion of the prairie biome (adapted from various sources).

Key to management is preventing populations of Greater Prairie-Chickens from becoming small and isolated, for this sets the stage for populations to fall below some critical threshold needed to maintain genetic integrity. Birds using fragmented grasslands (due to woody plant invasion and conversion of intervening lands to unsuitable habitat) may experience increased predation rates compared to those using more expansive grassland habitats. Approximately $30 \%$ of the grassland in a management unit should provide spring nesting cover with a minimum visual obstruction reading (VOR) of $25 \mathrm{~cm}$ and should be accessible to brood cover. In western parts of the species' range, this minimal cover value may be lacking as a result of heavy or early grazing, often preceded by extensive spring burning to increase forage value and livestock utilization. Inadequate precipitation commonly limits nesting, brooding, and roosting cover in the western parts of the species' range but precipitation may be excessive in the eastern portion of the range, particularly if it occurs during the brooding season. Excessive precipitation also may accelerate woody plant invasion and hamper habitat management efforts. In the eastern portion of the species' range, cover must be managed by rotational burning, mowing, grazing, or seed harvesting in order to maintain proper height, density, and grassland vigor, and to reduce woody plant invasion and excessive litter buildup. This is true for native grasslands as well as planted Conservation Reserve Program (CRP) grasslands. Woody plant succession and tree plantings in grasslands are serious detriments to Greater Prairie-Chicken habitat because woody vegetation 
replaces grassland vegetation, reduces required open horizons, and provides hunting perches for raptors. Habitat management to reduce predation by mammals and raptors is a priority concern. A portion of the agricultural landscape (perhaps 25\%) in cropland is important throughout the range but especially in more northern areas where excessive snow cover may limit winter food. The following account does not address population or harvest management but rather focuses on habitat management.

\section{Breeding range:}

Historically, three races of Greater Prairie-Chicken (Tympanuchus cupido) occurred in North America, the Greater Prairie-Chicken (T. c. pinnatus), Attwater's Prairie-Chicken (T. c. attwateri), and Heath Hen (T. c. cupido). This account deals only with T. c. pinnatus and not with the Attwater's Prairie-Chicken, which breeds only in a localized area in Texas, or the now extinct Heath Hen, which occurred on the East Coast. The Greater Prairie-Chicken is a year-round resident that breeds in disjunct populations from eastern North Dakota and western Minnesota, south through central South Dakota, central and southeastern Nebraska, to northeastern Colorado, northern and eastern Kansas, southern Iowa, northern and westcentral Missouri, northeastern Oklahoma, and east to central Wisconsin and southern Illinois (National Geographic Society 1999). It occurs mainly in the tallgrass portion of the grassland biome but extends westward into the mixed-grass prairie, particularly where land-use changes have supplemented food and cover. The species has demonstrated a remarkable amount of adaptation to different habitat conditions, considering its current widespread, and especially its historic, range (See figure). The historical extent of the tallgrass prairie may approximate the presettlement range of the Greater PrairieChicken except at the northern limit, which was apparently only along the southern edge of Minnesota and perhaps only the eastern edge of South Dakota (Hamerstrom and Hamerstrom 1963). For more information on habitat use by and effects of management practices on the Attwater's Prairie-Chicken, see Lehmann (1941) and Silvy et al. (1999). For information on the Heath Hen, see Gross (1928).

\section{Suitable habitat:}

The Greater Prairie-Chicken is a grassland bird. More specifically, it is a tallgrass prairie bird in terms of its presettlement distribution, but increasing evidence suggests that undisturbed (and tall and dense) tallgrass prairie was probably suboptimal habitat for Greater PrairieChickens. To state that it is a grassland bird oversimplifies how it uses its habitat to satisfy its seasonal life history requirements. The following section separately discusses habitats used for different key functions: mating, nesting, brood rearing, roosting, and foraging. It should be emphasized that the relationships between a bird and its habitat are importantly affected by many factors such as climate, predation, disease, pesticides, and genetics.

Lek Sites.-Male Greater Prairie-Chickens are able to perpetuate their genes only through mating with females, so males should maximize the likelihood of encountering and mating with females, and mating should be in the vicinity of good nesting cover. Furthermore, males should display in a setting (a lek or booming ground) where their visibility to females is maximized along with their security from mammalian and avian predators; that is, being seen and being able to see. Greater Prairie-Chickens display in areas of bare ground or short $(<15 \mathrm{~cm})$ cover, and these frequently are areas where cover has been reduced by burning, mowing, grazing, or cultivation. Occasionally lowland swales are used where snow has flattened the vegetation.

Nesting Habitat. - In the northern Great Plains, Greater Prairie-Chicken females begin nesting about the third week in April (Svedarsky 1979, Newell 1987). Generally, little new 
growth has occurred by that date, so hens select residual cover from the previous year. Natural selection favors females that select sites where the chances of producing offspring, and perpetuating their genes, are maximized. For females to increase the chances that copulations will lead to production of young, nesting cover must be within reasonable proximity to males on a booming ground. However, in Kansas, females moved 2-5 km from leks, where mating occurred, to nest sites (Robel, unpublished data). The nest site must provide concealment cover from predators but, in the event of discovery by a predator (usually a mammal), also must provide an unobstructed escape route that allows upward flushing from the nest. The nest site must provide shade from the sun and some protection from weather events such as intense rains, hailstorms, and flooding. It must be reasonably close to energy- and protein-rich food resources that are needed by the female during preincubation, laying, and incubation periods. Nests also must be situated so that the chicks have access to appropriate cover. Reported Greater Prairie-Chicken nest characteristics vary due to the broad geographical range of the species, but also might reflect the use of different measuring procedures (Buhnerkempe et al. 1984). Commonly, "height" is mentioned or summarized in the literature, but it is not clear whether that indicates the maximum height of any part of the vegetation, usually flowering stems, or the height of the vegetative components that conceal a nesting female or her nest. Newell (1987:16) used "height" to indicate maximum height and used effective height as that level below which all dots on a cover board were obscured by vegetation, similar to the $100 \%$ VOR of Robel et al. (1970a). To compare structural features of Greater Prairie-Chicken nesting cover, it is important to use consistent terminology and techniques. To minimize disturbance to hens, it is important to measure conditions at the time of nest-site selection or perhaps just before egg laying. New growth or activities that remove cover can substantially alter conditions if measurements are taken later in the season.

In Illinois, Westemeier (unpublished data) estimated averages for "effective height" (Mussehl 1963:549) of both dead residual and current year growth that concealed 868 prairiechicken nests, i.e., both estimates were made at the time nests were found (mostly late May to early July 1963-1991). Residual cover from previous year(s) in which most hens initiated their nests averaged $36 \mathrm{~cm}$, whereas new vegetation had grown to an average of $74 \mathrm{~cm}$. For all cover types combined, these heights did not differ for successful and failed nests. Similarly, Buhnerkempe et al. (1984:385) measured residual vegetation in February and March and concluded that "habitat should be managed so that $90 \%$ of the standing vegetation is distributed below $40 \mathrm{~cm}$ and the vertical aspect of vegetation should be dense up to that level. The highest vegetation in the field should not exceed $80 \mathrm{~cm}$." This cover should have a 100\% VOR of about $27 \mathrm{~cm}$ (Svedarsky 1979). The growth form of smooth brome (Bromus inermis) often may meet the above criteria because the majority of leaves are positioned on aerial stems, as opposed to being positioned at the base of the plant. Brome also withstands snow flattening if maintained in a vigorous condition. Few seed heads developed on brome in southern Illinois, which limited rankness (Westemeier, unpublished data). Interestingly, Greater Prairie-Chickens transplanted from Minnesota and Kansas to Illinois showed similar nesting cover preferences (brome, redtop [Agrostis stolonifera], timothy [Phleum pratense]) to Illinois birds, and fields where 11 birds successfully nested had 100\% VOR's of $20 \mathrm{~cm}$ in late March (Westemeier et al. 1995). By hatching time (about 1 June), VOR's averaged $40 \mathrm{~cm}$ in Illinois, and in contrast to the slow greenup of native grasses, introduced cool-season grasses such as smooth brome and timothy provided early concealment for nesting prairie-chickens. In a Minnesota study area with a variety of native and non-native cover types, Svedarsky (1988) found that Greater PrairieChickens strongly preferred smooth brome; 22 of 36 nests were found in brome, which 
composed only $2.9 \%$ of the study area. This is not to recommend smooth brome, which is an introduced species, over native species, because smooth brome can invade and degrade native prairie, but the structural features and rapid greenup of brome might be used as a reference in managing whatever cover is available in order to optimize Greater Prairie-Chicken nesting cover. Plant species composition in itself is not important as long as structural requirements are met. Greater Prairie-Chickens have existed for many years in Wisconsin on "substitute prairie" dominated by Kentucky bluegrass (Poa pratensis) (Hamerstrom et al. 1957:12) and by redtop and timothy fields in Illinois (Westemeier 1980). Quackgrass (Agropyron repens) is currently a dominant species in Wisconsin habitats used by prairie-chickens.

Westemeier (1973) found that Greater Prairie-Chickens avoided tall ( $>1 \mathrm{~m}$ ), native vegetation in Illinois. He believed that females were most secure in a setting where they can stand, survey the surrounding area, and readily flush, rather than run, if threatened. Of 40 successful nests in seeded native grass stands that were subject to different management practices during the late growing season prior to nesting, nest density was higher in high-mowed (mean of $48 \mathrm{~cm})$ stands $(0.15$ hatches/ha) than in disturbed $(0.06$ hatches/ha) or hayed $(0.05$ hatches/ha) stands (Westemeier, unpublished data). These findings are consistent with earlier data (Westemeier and Buhnerkempe 1983). Yeatter (1943), Hamerstrom et al. (1957), Svedarsky (1979), and Toepfer (1988) also believed that vegetation can become too tall and dense for nesting Greater Prairie-Chickens.

Litter usually is not separated from "residual vegetation" in the literature, but litter, as used here, is that part of the residual cover that is horizontally oriented and typically older than one growing season. Residual cover is accumulated growth from past years, but usually the growth from the previous year provides the majority of the concealment cover. Svedarsky (1979) and McKee et al. (1998) found the amount of litter to be inversely related to nesting success. Of several nest characteristics, McKee et al. (1998) found litter cover to be the best single predictor of nest success; nests with $>25 \%$ litter cover failed at twice the rate of nests with $<25 \%$ litter cover. They related increased litter to decreased grass and forb cover at nests. Buhnerkempe et al. (1984) found unsuccessful nests primarily in fields with mean litter depths of $5.6 \mathrm{~cm}$, whereas successful nests were in fields with mean litter depths of $4.2 \mathrm{~cm}$. In a sample of 513 nests in western Minnesota, Toepfer (unpublished data) found that apparent nest success in CRP (with presumably deeper litter due to no-disturbance management) was 33.1\% of 204 nests during 1992-1996 and 47.6\% of 166 nests during 1997-2001. Success in native prairie was $55.4 \%$ of 101 nests and $55.8 \%$ of 42 nests, respectively, for the same periods. Percent of nests in CRP compared to native prairie was $66.9 \%$ of 305 nests in the first period and $79.8 \%$ of 208 nests in the second period, suggesting a greater attractiveness of nesting hens to CRP versus native cover or increased availability of CRP. These CRP habitats originally were planted to smooth brome and alfalfa, although currently alfalfa is mostly absent. Both increasing litter depths and changing vegetation density may have contributed to Greater Prairie-Chicken declines on Soil Bank lands in North Dakota, 5-7 years after seeding (Kirsch et al. 1973). Excessive litter could indirectly reduce nest success by enhancing small-mammal habitat and thus attracting red foxes (Vulpes vulpes) or by providing better conditions for June beetle (Phyllophaga spp.) larvae and thus attracting striped skunks (Mephitis mephitis) (Svedarsky 1979). During a 15-year Illinois study, density of small-mammal nests was highest (12.8/ha) in undisturbed prairie grasses compared to high-mowed (10.5/ha) or hayed (7.3/ha) stands (Westemeier and Buhnerkempe 1983). One might expect predation rates on prairie-chicken nests to decline if, in fact, the alternative prey base increased due to litter buildup. In Minnesota, Kimmel et al. (1994) evaluated cover characteristics of warm-season and cool-season grasses in 
CRP plantings after establishment. They found percent litter cover increased with stand age for cool-season plantings but not for warm-season plantings. Litter depth, however, was not related to stand age in either type of planting. VOR's declined with age of cool-season grass stands but increased with age of warm-season grass stands. This suggests that it is more important to regularly rejuvenate cool-season grass cover for optimal residual cover than to rejuvenate warmseason grass cover.

During a 29-year Illinois study, nest productivity was measured by number of hatched nests per unit of habitat type. From a sample of 476 hatches, smooth brome had 0.24 successful nests/ha, followed by timothy (0.16), redtop (0.13), prairie grasses $(0.08)$, weedy herbaceous (0.08), and wheat stubble/legume (0.04) (Westemeier, unpublished data). These data are consistent with an earlier report (Westemeier 1985). Brome tends to maintain a more vertical position than do native species (in this case, mostly switchgrass [Panicum virgatum], Indiangrass [Sorgastrum nutans], and big bluestem [Andropogon gerardii]). At least in Illinois, Westemeier (1985:35) believed brome more closely resembled a "seed it and leave it" cover than any other grass cover used on prairie-chicken sanctuaries. Westemeier (1988) found higher nest densities of prairie voles (Microtus orchrogaster) and southern bog lemmings (Synaptomys cooperi) in prairie grass (5.13 nests/ha) and lower nest densities in brome (2.10 nests/ha), and suggested that the lower productivity in planted native stands resulted from an increased attraction for mammalian predators in that habitat.

Svedarsky (1979) in Minnesota and McKee et al. (1998) in Missouri found that the presence of woody vegetation lowered Greater Prairie-Chicken nest success. McKee (1995) reported that 15 of 26 (57.7\%) clutches hatched when woody cover was $\leq 5 \%$, but only 3 of 17 (17.6\%) clutches hatched when woody cover was $>5 \%$. Woody vegetation may produce an edge effect that encourages mammalian predators to hunt in an area and may provide perch sites

for potential avian nest predators, such as American Crow (Corvus brachyrhynchos) and Black-billed Magpie (Pica hudsonia).

Dense vegetation is thought to offer a barrier to predators because nests placed close to cattle trails experienced higher losses to predators than those placed farther from cattle trails (Capel 1965). Kirsch (1969) found that red foxes readily used vehicle trails as access routes into idle cover. In Illinois, high-mowed $(33-48 \mathrm{~cm})$ stands had evenly spaced wheel tracks from combines, from baling and hauling residue, and from rotary mowing (Westemeier, unpublished data). Nests concealed mainly by timothy, brome, and prairie grasses showed highest success (63\%, 62\%, and 46\%, respectively) in stands that had been high mowed prior to nesting seasons. However, nest success in redtop was highest (63\%) in stands that had been left undisturbed through the summers and falls prior to nesting. "High” mowing of redtop by lessees was often too short $(<30 \mathrm{~cm})$ compared with mowing by managers in timothy, brome, or restored prairie grasses $(>30 \mathrm{~cm})$. Thus, vehicle tracks do not necessarily foster high predation, at least not in fields uniformly covered with wheel tracks and those mowed at sufficient height (Westemeier, unpublished data). Robel (unpublished data) suggested that some grazing can enhance nesting use of Kansas prairies by opening up dense stands.

Brood-rearing Habitat.-Early reports indicated that broods stayed in the vicinity of the nest for the first few weeks after hatching (Schwartz 1945, Hamerstrom and Hamerstrom 1949), advancing the notion of "nest-brood habitat" (Hamerstrom et al. 1957, Westemeier 1971, Kirsch 1974, Drobney and Sparrowe 1977). The mosaic of diverse habitats and smaller agricultural fields in the 1940's may have better facilitated movements of chicks from nests to suitable brooding areas close to nests than do current large fields and crop monocultures with few weeds. The advent of radio-telemetry in the early 1960's (Marshall 1963) made it possible to document 
movements and habitat use by wildlife without directly observing marked animals. Previously, this could not be done, particularly in dense habitats, and thus our knowledge of upland game bird ecology greatly increased (Robel et al. 1970b). "Nest-brood habitat” suggests a given habitat that is used for both nesting and brooding, which may be true in some situations. For Greater Prairie-Chickens, the term may be used in a general sense. For example, in Minnesota, "bluestem" habitat might have been termed "nest-brood habitat" but, specifically, undisturbed bluestem was "nesting” habitat and recently ( $\leq 1 \mathrm{yr}$ ) burned, grazed, or hayed bluestem was "brood” habitat (Svedarsky 1979). Generally, brood habitats differ from nesting habitats. Brood habitat must accommodate chick movement at ground level, provide adequate amounts and kinds of insects, provide concealment from predators, provide protection from weather factors, provide openings for sun exposure and dusting, and must be accessible from the nest site because chicks have to walk from the nest. Nesting habitat, on the other hand, must be dense enough to conceal the female, provide for predator detection and escape, and may be widely separated from feeding areas due to the greater mobility of females. Perhaps Jones (1963:757) was the first to recognize this difference in Oklahoma: "Nesting took place in areas of exceptionally heavy cover. When hatching was completed, Greater Prairie-Chicken females moved their broods into areas where the vegetation had been disturbed: old fields, native shortgrass, or cultivated pastures.” Disturbance seems to be a common denominator of good brood habitat as long as there is adequate regrowth to provide insects and to provide cover from predators and weather factors. In Minnesota, Svedarsky (1979) reported that broods moved directly from nests to areas that had been disturbed by burning, grazing, or haying; these habitats accounted for over $69 \%$ of 290 brood locations. Studies in other areas in the eastern portion of the range have noted similar patterns (Skinner 1977, Burger 1988, Jones 1988, Toepfer 1988, Westemeier et al. 1995). This is not to say, however, that hens cannot raise broods in undisturbed areas. Toepfer (unpublished data) observed that hens successfully raised broods in CRP fields in Wisconsin and Minnesota that had not been disturbed for $>10$ yr. In the western part of the prairie-chicken range, where grazing is a more common land use, availability of disturbed areas per se may not be as limiting as areas containing adequate concealment cover in combination with adequate insect abundance.

In a study on the Ft. Pierre National Grassland in South Dakota, Rice and Carter (1982:18) pooled brood data from 13 radio-tagged Greater Prairie-Chickens, nine Sharp-tailed Grouse (Tympanuchus phasianellus), one hybrid, plus incidental observations and noted that “... sweet clover (Melilotus spp.), snowberry (Symphoricarpos spp.), and good stands of western wheatgrass (Agropyron smithii) and green needlegrass (Stipa viridula) were most commonly used for brooding habitat. Some use of vegetation associated with unmowed road ditches and stock dams was recorded. Birds were often located along drainages and on north-facing slopes.” Quantitative data were not given, but the implication was that the heaviest cover available was sought by broods, especially during the hottest part of the day. At the Sheyenne National Grassland (SNG) in southeastern North Dakota, Newell et al. (1988b) found that broods used vegetation $>25 \mathrm{~cm}$ tall an average of $80 \%$ of the time during summer months.

In evaluating reports of brood habitat use, especially concealment cover, one should consider the method or circumstances of detection. An observer on foot without a dog would likely see more broods in more open cover, where birds would be more apt to flush. Searching with one or two dogs, accompanied by various vocal commands, would likely alert broods at a greater distance and they could seek heavier cover, if available. The latter could bias observations of brood habitat use toward denser cover. Incidental observations made while harvesting hay would be biased towards the use of hay fields. Judiciously collected radiotelemetry data probably are the least biased because radio telemetry allows locating broods in 
settings where incidental observations would be unlikely due to the reluctance of birds to flush in heavy cover, or in areas where an observer decides that a particular cover type would not be a good place to find broods. In following radio-tagged broods in Wisconsin, Toepfer (1988:439) noted that "The consistent use of the taller grasses is probably the main reason why prairiechicken broods are rarely seen.”

Lowlands (areas that contain sedges [Carex spp.] and usually are wet in spring) seem to be important to prairie-chicken broods in grazed areas of the northern Great Plains. Newell et al. (1988a:26) collected 921 radio locations from 36 Greater Prairie-Chicken broods on the SNG and recorded most locations in the lowland community, "with the highest use occurring in June when lowland vegetation was much taller and denser than upland or midland vegetation." During all summer months, they found that over $44 \%$ of the locations in lowlands had VOR's $>25 \mathrm{~cm}$. In Minnesota, Svedarsky (1979) found that lowland habitats (willow [Salix spp.], sedge had positive brood preference ratings when burned or grazed but had negative ratings when undisturbed, suggesting differences in openness at ground level and/or in insect abundance. Broods may use lowlands because lowlands provide taller cover or because of advantages in predator avoidance. In Wisconsin, Gratson (1988) found half as many small mammals in lowlands than in uplands, and suggested that this may have decreased hunting pressure in lowlands by predators such as red foxes.

In addition to the functions described above, brood habitat also must function as secure roosting cover. Broods, especially young ones with limited mobility, do not move to optimal roost habitats at the end of the day but rather roost where they happen to be.

Insects are the primary food source for young galliforms, especially during the critical first two weeks. In Oklahoma, Jones (1963) found that insects (mostly beetles [Coleoptera] followed by grasshoppers [Orthoptera]) composed 97\% of 14 Greater Prairie-Chicken brood droppings. Rumble et al. (1988:51) found that "arthropod parts" (mostly insects) composed an average of $84.6 \%$ of 75 Greater Prairie-Chicken brood droppings collected in June, July, and August at the SNG. Forbs in general and legumes in particular are associated with desirable insect quantities and brood habitats. Jones (1963:773) wrote that "counts of insects captured in the various habitat types revealed that the vegetation with the greater percentage of forbs consistently had more insects per unit area than did the other vegetational associations...” and that "... the cultivated pasture association was the cover most frequently selected by birds with broods. This cover was dominated by low weeds and annual lespedeza (Lespedeza spp.).” In Missouri, Drobney and Sparrowe (1977) noted that legumes covered only 1\% of their study area but accounted for 19\% of all brood observations. In a Ruffed Grouse (Bonasa umbellus) study in Tennessee, Hollifield and Dimmick (1995) found nearly twice as many arthropods on logging roads seeded to clover (Medicago spp.) than on roads seeded to timothy. Legumes also may be consumed directly by broods. Rumble et al. (1988) found that alfalfa (Medicago sativa) and sweet clover leaves composed $7.4 \%$ of the June diet at the SNG, second only to arthropod parts that made up $80.1 \%$. Kobriger (1965) noted that one of the reasons that wet meadows were attractive to grouse broods at Valentine National Wildlife Refuge in Nebraska was the clover (Trifolium spp.) and dandelions (Taraxacum spp.) that grew there. N. J. Silvy (Texas A\&M University, College Station, Texas, pers. comm.) noted that Attwater's Prairie-Chicken chicks cannot develop properly on a pure diet of insects, but rather "they need some greens."

Southwood and Cross (1969) evaluated insect abundances in different habitats and related these to the needs of growing Gray Partridge (Perdix perdix) chicks. The minimum daily distances needed to obtain sufficient insects in five different habitats by 7-day-old partridges were estimated as follows: 


\begin{tabular}{|l|l|}
\hline Downland (wild grassland) & $101 \mathrm{~m}$ \\
\hline Unsprayed (weedy) barley field & $163 \mathrm{~m}$ \\
\hline Uncut grass (hayfield) & $174 \mathrm{~m}$ \\
\hline Grass/clover (grassland) & $254 \mathrm{~m}$ \\
\hline Herbicide-treated barley field & $557 \mathrm{~m}$ \\
\hline
\end{tabular}

Although these values are for a different species than Greater Prairie-Chickens, the concept is applicable. Comparative movements required in different habitats are of interest because movements require energy and increase exposure to predation. It is noteworthy that the reduction of weeds (presumably mostly forbs) by herbicide use in barley fields decreased insects more than three-fold compared to unsprayed barley fields. The reduction in insects caused increased movements of chicks to obtain food.

The proximity of brood habitats to nests can affect early brood movements. Svedarsky (1979) recorded average minimum movements of about $2 \mathrm{~km}$ for nine prairie-chicken broods during their first week. Newell (1987) recorded average movements of $0.47 \mathrm{~km}$ from nests to the first intensive-use areas by 20 Greater Prairie-Chicken broods at the SNG. In Kansas, Silvy (1968) and Viers (1967) each observed a Greater Prairie-Chicken brood that moved $3.2 \mathrm{~km}$ from the nest in six and seven days, respectively. Newell (1987) reported a 12-day-old brood that moved $10.3 \mathrm{~km}$ in eight days. Both Svedarsky (1979) and Newell (1987) documented extensive early movements of broods and high brood mortality, prompting them to suggest that broodrearing habitat, or at least the brood-rearing period, is a very important limiting factor. Rice and Carter (1982:18) related movements to cover height: "During the severe drought of 1976, movement up to $1.6 \mathrm{~km}$ in a 24-hour period was not uncommon. In 1978, when vegetation conditions were good, movement by hens was considerably less than previous years as birds were never recorded more than $0.4 \mathrm{~km}$ from nest sites.”

The nutrition of brood hens in relationship to habitat may affect brood survival. Zwickel and Bendell (1967) evaluated prehatching influences in Blue Grouse (Dendragapus obscurus) and noted that chicks from wild-collected eggs reared in captivity had similar mortality patterns as same-year chicks reared in the wild. They found no evidence, however, that this reflected upon the nutritional state of the hen, although having access to protein-rich food resources during the prelaying and laying periods should be as important for grouse as it has been shown for waterfowl (Krapu 1974, Swanson et al. 1974). The spring and early summer nutritional requirements of female prairie grouse are not as well known as those for waterfowl, but the two avian groups should share some physiological similarities, including body size, egg size, precocial young, and persistent renesting (at least in the northern parts of the prairie-chicken's range). Although more definitive research is needed, food plots and agricultural crops may have critical but generally unrecognized importance to egg-laying females as well as to broods. What Hamerstrom (1963:793) pointed out for Sharp-tailed Grouse broods in Wisconsin may be even more true for Greater Prairie-Chicken hens and broods in the northern prairies: “... food patches may have an unappreciated value for summer food. The greens and insects which accompany cultivation may be even more important than the grains which have been planted." Broodhabitat values of early agriculture on the northern prairies (small pastures, weedy cropland, abundant field edges, poor drainage preventing replanting of some cropland) may have been as 
important as waste and field-stored grains (bundles, shocks) in winter in the northward and westward range expansion of the Greater Prairie-Chicken following European settlement of the prairies.

The brood period represents an excellent example of the interaction of ecological factors. The early-season nutrition of the female may have prelaying influences on chick survival; chicks must find adequate amounts and kinds of insect food; and climate (especially temperature and precipitation) can determine insect availability as well as foraging opportunities of chicks. Chicks must be able to move through foraging habitats, which provide cover from weather and predators for hens and broods. Land management activities, such as haying, grazing, and grain harvesting, can have direct (e.g., injuries from harvesting equipment) or indirect (e.g., additional predation resulting from cover removal and induced movements) effects on chicks. There can be many weak links in this system. Svedarsky (1979) believed that brood-rearing habitat and associated conditions were a greater limiting factor in Minnesota than nesting cover due to extremely low brood survival. Newell et al. (1988b:30) found that, "Mortality of chicks was very high, with only $28.4 \%$ of the chicks surviving to the end of the summer" and suggested that the population declines at the SNG may be, in part, due to poor brood survival.

Roosting Habitat.— "Roosting” as used here will refer only to night-time activities and will not include “day roosts” (Hamerstrom et al. 1957, Manske and Barker 1988, Toepfer 1988). Furthermore, roosting cover can be separated according to the snow-free season, when birds utilize vegetation, and the snow season, when birds commonly burrow into snow if sufficient depths are available (Rosenquist 1996). Leopold (1931) noted reports of birds roosting in trees, but some of the reports may have been late-evening sightings after which birds moved to the ground to roost. Greater Prairie-Chickens are capable of flight under very low-light conditions. Most, if not all, night roosts are on the ground.

Greater Prairie-Chickens spend over one-half of their lives on a roost, especially in the North where winter nights are long. Roosting sites must provide a measure of protection from weather. Equally important, roosting sites must provide safety from predators, such as reducing detection or facilitating escape from predators in case of detection. Roosting cover is critical year-round, but perhaps more so in the winter when it is closely tied to food resources. Roost sites should be near adequate winter food resources in order to minimize movements that utilize energy and increase exposure to predators. In Missouri, Burger (1988:88) noted that "Our observations suggest that prairie chickens select optimal winter roosting habitat, then make daily feeding movements radiating as far out from this habitat as necessary to meet energetic demands." Roosting habitat may be more limiting than food in more snow-free areas. Farther north, food may be more limiting, but it needs to be accessible from night roosts. In Wisconsin, Schmidt (1936:197) suggested that "Food determines what range is habitable in winter, but so does cover, particularly roost cover." Hamerstrom et al. (1957) believed that winter cover was not limiting when the herbaceous vegetation was covered with snow because birds used woody cover, which is fairly abundant in the Wisconsin portion of the Greater Prairie-Chicken range. In a photo caption, Hamerstrom et al. (1957:57) noted that "Here bluegrass is (matted) down, under ten inches [25 cm] of snow, but sedges, quack, timothy and Muhlenbergia still give roosting cover." Later, using radio-tagged birds, Toepfer (1988) found that $57.1 \%$ of 175 winter roosts in northwestern Wisconsin were in "wetland” habitat and that $51.8 \%$ of 307 locations in central Wisconsin were in "wetland/shrub” habitats.

Manske and Barker (1988) identified the following as winter roosting habitats at the SNG in North Dakota, based on incidental observations of prairie grouse (Sharp-tailed Grouse and Greater Prairie-Chickens) roost sites: switchgrass portion of midland community, shelterbelts 
and other woody vegetation along cropland edges, and snow when it was $>30 \mathrm{~cm}$ deep in drifts along shelterbelts and the lee side of hummocks. Toepfer and Eng (1988) followed 20 radiotagged Greater Prairie-Chickens at the SNG. The authors found that 64\% of 525 night locations were in lowland grass and shrubs, $13.7 \%$ were in reed canary grass (Phalaris arundinacea), $11.8 \%$ were in shrubs, $7.4 \%$ were in midland grasses (primarily little bluestem [Schizachyrium scoparium]), and 7.1\% were in quackgrass. Manske and Barker (1988) recorded no winter night roost sites in the "lowland grassland" habitat type, but they were not using radio-tagged birds.

Because lowland areas tend to support taller vegetation than upland areas, lowlands may possess characteristics that are advantageous for Greater Prairie-Chickens in predator avoidance as well. Gratson (1988) suggested that canid predators spend comparatively less time hunting small mammals in lowlands, which may reduce their chances of finding roosting prairie grouse. He also suggested that, in Wisconsin, there tended to be fewer trees in wetlands that could serve as hunting perches for Great Horned Owls (Bubo virginianus), a nocturnal and crepuscular predator. Gratson (1988) also discussed the possible predator-avoidance strategy of birds changing roost sites because predators may return to sites of previous prey captures. Toepfer and Eng (1988) found that the average distance between successive night locations was $922 \mathrm{~m}$, indicating that prairie-chickens shift roosting sites.

In northwestern Minnesota, Rosenquist (1996) found that several habitats were used for roosts, but that areas with forbs, especially alfalfa and goldenrod (Solidago spp.), appeared to provide the best snow-burrowing conditions. CRP lands with smooth brome and alfalfa were used when snow conditions permitted burrowing. Native prairie was rarely used because of snow packing. Willow areas received little direct use, although the associated herbaceous vegetation within willow complexes often was used because it tended to accumulate snow that provided good burrowing conditions. Birds rarely roosted under willow branches and, on one occasion, a roosting bird was apparently depredated by a coyote (Canis latrans) when the grouse flushed up into willow branches from a snow burrow (Rosenquist 1996).

Toepfer and Eng (1988) reported that $>89 \%$ of the winter night locations at the SNG were in cover $>25 \mathrm{~cm}$ tall. For vegetation at 32 roosts, VOR's averaged $21 \mathrm{~cm}$. Manske and Barker (1988) did not separate data for roosts by season, but found that the average VOR's for night roosts throughout the year was $19 \mathrm{~cm}$ (range 15-22 cm). From these data, they concluded that " $15 \mathrm{~cm}$ is the minimum level for good night roost habitat" (Manske and Barker 1988:18). If one considered the midpoint of a range or a mean to indicate "good" roosting habitat, an alternate view would be to average Toepfer and Eng's (1988) $21 \mathrm{~cm}$ for cover types with Manske and Barker's (1988) overall VOR of $19 \mathrm{~cm}$ for roosting sites throughout a year, which would yield $20 \mathrm{~cm}$ as a standard of "good" winter roosting cover, at least at the SNG.

McKee (1995) collected roost data for all seasons in Missouri and found an average VOR of about $20 \mathrm{~cm}$ (range 10-35 cm), but no pattern of site selection was apparent. In Colorado, Schroeder and Braun (1992:16) indicated that "Roosting typically occurred in mid and tall vegetation in relatively dense grassland areas in all seasons," but they presented no quantitative data to support this statement.

In Oklahoma, Jones (1963) reported the following vegetation heights for night roosts by season: $13 \mathrm{~cm}$ in winter, $4 \mathrm{~cm}$ in spring, $32 \mathrm{~cm}$ in summer, and $5 \mathrm{~cm}$ in fall. These values are perhaps biased toward shorter cover because Jones was not working with radio-tagged birds, and because roosting grouse are more difficult to locate in heavier cover. Toepfer (1988), following radio-tagged Greater Prairie-Chickens in Wisconsin, found that vegetation $<25 \mathrm{~cm}$ tall was regularly used during the day but not during the night, when about $90 \%$ of locations were in 
cover $>25 \mathrm{~cm}$ tall. "Grass/forbs” was a major habitat used in all four seasons in central Wisconsin, followed by "upland grass."

In Michigan, Ammann (1957:61) pointed out that "Marshes and bogs are often sought as roosting cover, particularly by prairie chickens, even though these cover types may not serve any other purpose, and the birds may fly a mile $[1.61 \mathrm{~km}]$ or more from the most-frequented part of the area to reach them. Generally speaking, prairie chickens seem to be more exacting in their choice of roosting cover. They show a preference for the lowland types if the water level is not so high as to prevent their finding dry spots.” In Minnesota, Svedarsky (1979) found that wetland communities accounted for $62.5 \%$ of the preincubation roost locations of radio-tagged females.

Foraging Habitat - Snow season.-Other than rose (Rosa spp.) hips and buds of shrubs and trees, native prairies in the North provide meager food resources for Greater PrairieChickens under winter snow cover, and this portion of the foraging ecology will be discussed separately from the other three seasons (see below). Hamerstrom et al. (1941:192), after an experimental feeding study, concluded that “...browse alone will not carry prairie chickens through the winter. Small numbers may be able to supplement a browse diet with a certain supply of weed seeds, but to have prairie chickens in quantity in the North Central States, winter grains are necessary.” When and where did Greater Prairie-Chickens come to use or rely on agricultural crops in the winter? Hamerstrom et al. (1941) believed that it was unlikely that prairie-chickens evolved with the development of primitive agriculture but rather adapted to it when it became available and, by altering their feeding habits, were able to greatly extend their range far north of the original limits. In two Missouri studies of fecal droppings collected in winter, agricultural crops made up at least 68.2\% (Korschgen 1962) and 51.9\% (Toney 1980) by volume. Kobriger (1965:789) noted that "Prairie chicken populations shrank as corn acreages decreased, and today the eastern and southern sandhill borders, with both grasslands and corn, support the best prairie chicken populations in Nebraska.” Schmidt (1936:200) also spoke of the importance of corn: "Increase in prairie chicken population and an extension of range resulted from the extensive growing of corn by the early settlers.” Manske (1987) closely followed the winter habitat use of prairie grouse at the SNG and noted heavy use of corn and sunflower (Helianthus annuus) fields and waste grain spilled along railroad tracks bisecting the SNG. He noted that Greater Prairie-Chickens pick undigested grain out of cow manure in the winter and believed that high-energy winter food is the primary limiting factor for prairie grouse on the SNG. Rumble et al. (1988) found that agricultural crops (corn, sunflowers, and soybeans) made up 72.0, 61.3, and 65.2\% of the diet of SNG prairie chickens in the months of December, January, and February, respectively. In comparison, shrubs made up 0.2, 0.9, and 2.7\%, respectively. Toepfer and Eng (1988) determined 3945 winter locations from radio-tagged Greater Prairie-Chickens on the SNG and found that agriculture accounted for $41 \%$ of the locations, and $70.8 \%$ of these were harvested corn. Observations of prairie-chickens feeding during the winter in North Dakota indicated that they prefer sunflowers over soybeans and soybeans over corn (Toepfer and Eng 1988). This was determined by watching radio-marked birds feeding in three adjacent agricultural fields. Before snow cover, birds fed in sunflower fields. Once sunflowers were unavailable due to snow cover, birds shifted to adjacent windblown soybean fields between two harvested corn fields. When additional snow covered the soybeans, prairie-chickens began feeding in the harvested corn fields. When snow melted in late winter, birds shifted back to sunflowers fields.

Kirsch (1974) argued that winter food is not limiting for Greater Prairie-Chickens because they utilize buds and will move to winter food sources. But Hamerstrom et al. (1941) 
demonstrated that Greater Prairie-Chickens cannot live on buds alone, and Burger (1988) related increased mortality with increased movements. Toepfer (unpublished data) recorded increased movements and mortality from electrical wire collisions when snow changed food availability. Even if Greater Prairie-Chickens could survive at minimal population levels in the North without agricultural winter foods, it would seem prudent for populations that are in jeopardy to minimize movements that require energy and allow exposure to predators. Rosenquist and Toepfer (1995) monitored 224 radio-tagged Greater Prairie-Chickens over 5 yr in Minnesota and determined that food accessibility was a major factor influencing winter movements. Movements $>16 \mathrm{~km}$ were common in females moving from nesting to wintering areas, but males generally remained within $6.4 \mathrm{~km}$ of their "home" booming grounds. Small grains and sunflowers were preferred, but standing corn was used when other foods were covered with snow.

For the southern states within the Greater Prairie-Chicken range, Robel (unpublished data) noted that seeds of many prairie forbs are abundant in native tallgrass prairie and may provide a good source of winter food. However, management practices, such as herbicide use (Clubine 2002) that reduces forbs and increases grass composition, will reduce the availability of these natural foods and thereby increase the species' reliance on agricultural crops in winter.

Church et al. (1989) determined the combustible energy, gross energy, utilization efficiency, assimilated energy, and metabolizable energy from seeds reported to be eaten in the winter by Greater Prairie-Chickens and ranked them as follows:

\begin{tabular}{|l|l|}
\hline Excellent & millet, soybeans \\
\hline Good & sunflowers, lespedeza \\
\hline Fair & wheat, corn, sorghum \\
\hline Poor & buckbrush (Symphoricarpos spp.), pigweed (Amaranthus spp.), switchgrass \\
\hline
\end{tabular}

Foraging Habitat - Snow-free season.-This period of foraging is defined more by the snow-free period than by calendar dates and would generally commence in mid-March and last through perhaps mid-November in the Dakotas and Minnesota, subject to yearly variation. In the southern part of the range in Illinois, Kansas, Missouri, and Oklahoma, the entire year may be essentially snow-free during some years. Korschgen (1962) conducted an intensive foodhabit study in Missouri in which he analyzed 5040 droppings uniformly collected in the eight counties that occur in the species' range and with equal representation during all months. Grassland and agricultural habitats were intermixed in the study area at the time. Corn was the leading food item by volume throughout the year, followed by soybeans, sorghum, and Korean lespedeza (Lespedeza stipulacea). Native foods made up only $26 \%$ of the annual diet compared to agricultural items. Animal foods were generally of low importance, but Korschgen (1962) did not analyze chick droppings, and soft-bodied insects and larvae are more completely digested and may have been poorly represented in the samples. Toney (1990), about 20 years later, conducted a year-long study in a predominantly native prairie landscape in the Missouri range and found that native foods comprised over twice as much volume as in the Korschgen study. Wild rose (Rosa carolina) was most important by volume and occurrence, followed by corn, sorghum, and wheat. A number of native plants were used, depending on availability. In Kansas, Baker (1953) found similar trends to Korschgen's study: cultivated grains were important in winter months and greens (native and cultivated) were important in other seasons. Rumble et al. (1988) found that diets during the prenesting and incubation periods (April-May) 
at the SNG were dominated by dandelion (Taraxacum officinale) flowers, alfalfa, sweet clover, and corn. In Minnesota during this same period, Svedarsky (1979) commonly located radiotagged females in cultivated fields and in areas with short cover (grazed prairie or sparse vegetation on ridge tops) where dandelions and other plants were the first to green up. Rumble et al. (1988) found that arthropods increased in the diet of adult prairie-chickens in June. By August, arthropods composed nearly $60 \%$ of the diet. Alfalfa and sweet clover increased throughout the spring to $42 \%$ in June and then declined to 15\% in August. In late summer and fall, Greater Prairie-Chickens commonly shift their foraging to agricultural fields when available (Baker 1953, Korschgen 1962, Horak 1985, Horak and Applegate 1998). In Kansas, Horak (1985) compared Greater Prairie-Chicken food habits in a grassland with a cultivated area and concluded that "prairie-chickens are not dependent on cultivated crops but will use them when available." This could change in the more contiguous expanses of prairie if current management practices are reducing plant diversity (and the forbs) towards a domination by warm-season grasses (Howe 1994).

Water Use.-Greater Prairie-Chickens generally ingest needed water from succulent foods and dew on vegetation (Hamerstrom and Hamerstrom 1968, Horak 1985). During dry periods, surface water is used (Jones 1963, Horak 1985), but even in the driest parts of the range in Colorado, no emphasis is placed on the management need to provide surface water (Schroeder and Braun 1992). A table near the end of the account lists the specific habitat requirements for Greater Prairie-Chickens by study.

\section{Area requirements:}

The Greater Prairie-Chicken is considered an area-sensitive species that requires large expanses of grassland in a relatively open condition (Hamerstrom et al. 1957, Sample and Mossman 1997). Populations in the eastern portion of the range may be somewhat more tolerant of smaller habitat units than western birds. In Michigan, Ammann (1957) suggested $10.2 \mathrm{~km}^{2}$ as a minimum area requirement. In Wisconsin, Grange (1948) suggested 23-61.4 $\mathrm{km}^{2}$ for summer range, and Hamerstrom et al. (1957) suggested $10.2 \mathrm{~km}^{2}$. In Nebraska, Mohler (1952) believed fall ranges were $\geq 23 \mathrm{~km}^{2}$. Kirsch (1974) recommended $5.1 \mathrm{~km}^{2}$ as a minimum area for habitat that is intensively managed. He based this largely on the dramatic population response achieved in Illinois by intensively managing $5.3 \mathrm{~km}^{2}$ (Westemeier and Vance 1972) and a similar area in Missouri where populations had been maintained for $>10 \mathrm{yr}$. However, subsequent to Kirsch's recommendation, both the Illinois (Westemeier et al. 1998a) (after nearly two decades of very high densities) and Missouri (Mechlin et al. 1999) populations, experienced dramatic declines. More recently, Westemeier and Gough (1999) suggested a minimum of $6.1 \mathrm{~km}^{2}$ in Illinois, assuming intensive management of the area is suitable for prairie-chickens (for leks, nesting, brooding, roosting, etc.). Niemuth (2000) analyzed land use around booming grounds in Wisconsin and suggested that habitat areas should be a minimum of $18 \mathrm{~km}^{2}$, of which $\geq 15 \%$ should be nesting cover. This was based on a 1-yr study, however, and many of those booming grounds moved or disappeared the next breeding season (Toepfer, unpublished data). In the northern tallgrass prairie of northwestern Minnesota and southeastern North Dakota, Greater Prairie-Chickens appeared to be highly sensitive to both patch size and landscape (Winter et al. 1998, 1999, 2000, 2001). Of 259 individuals that were detected during a 4-year study, 95\% occurred in large prairies (>200 ha) that were surrounded by neutral landscapes, i.e., landscapes surrounded by little woody vegetation, whereas $5 \%$ occurred in hostile landscapes, i.e., landscapes surrounded by woody vegetation. No individuals occurred in small ( $<50 \mathrm{ha})$ prairies. 
The advent of radio telemetry has provided more precise home range and movement information, which is of fundamental importance when evaluating the feasibility of reintroduction projects. Based on experience working with radio-tagged Greater PrairieChickens for $>20 \mathrm{yr}$, Toepfer et al. (1990) believed that 1600 ha of suitable habitat would be the minimum area needed to sustain a population containing 200-250 males in reintroduction projects. Such a minimum goal was planned for Illinois (Simpson and Esker 1997) and even more ambitious plans are underway. More recent work on movements (Halfmann et al. 2001) and genetic analysis of populations (Westemeier et al. 1998b, Bellinger 2001) suggested that even 1600 ha may be too conservative, although the area will depend on the nature of surrounding habitat and the proximity to other populations. Comparative genetic evidence of remnant populations suggests that the primary Minnesota range ( $272 \mathrm{~km}$ by $19 \mathrm{~km}$, or 516,800 ha) is the smallest "isolated" population that has maintained its genetic integrity (Toepfer, unpublished data). This range is composed of a mosaic of habitats, such as native and tame grasslands, brush, wetlands, croplands, and woodlands. Robel (unpublished data) believed that 2000-4000 ha would be the minimum area required to sustain viable populations in the more contiguous tallgrass prairie habitat of Kansas.

Area requirements vary both seasonally and with gender. Generally, movements are greatest during the winter and least during the breeding season. Males usually stay within $1 \mathrm{~km}$ of their "home" booming ground and females within $1 \mathrm{~km}$ of their nest (Toepfer 1988). However, this may be biased when small, isolated populations are studied in comparison to populations in the more expansive habitats of Kansas (Robel, unpublished data). Females are limited during the early-brood period by the mobility of their chicks. Furthermore, because Greater Prairie-Chickens are a lekking species, there is an "area requirement” or territory on the booming ground for males. For 10 territories on expansive grasslands in Kansas, the average size was $518 \mathrm{~m}^{2}$ (range 100-1060 $\mathrm{m}^{2}$ ), with more dominant males holding larger territories (Robel 1966).

\section{Brood parasitism:}

Interspecific brood parasitism has been reported. In Illinois, Westemeier et al. (1998a) reported that 74 of 676 prairie-chicken nests had been parasitized by Ring-necked Pheasants (Phasianus colchicus). Although nest success did not differ between parasitized and unparasitized nests, the productivity of prairie-chickens was reduced because of increased embryo mortality, increased nest abandonment, or because hens shortened the incubation period from the average 25 days for prairie-chickens to 23 days for pheasants, which resulted five times in near full-term prairie-chicken eggs being left in nests after pheasant eggs had hatched. Nest parasitism increased from 2 to 43\% over a 14-yr period and remained high for an additional 4 yr. In Minnesota, Carlson (1942) reported single pheasant eggs in two prairie-chicken nests. Hagen et al. (2002) reported no instances of pheasant parasitism of Greater Prairie-Chicken nests in the more expansive habitats of Kansas and found only 3 of 75 Lesser Prairie-Chicken (Tympanuchus pallidicinctus) nests were parasitized. In Illinois, Westemeier (unpublished data) found several prairie-chicken nests containing Northern Bobwhite (Colinus virginanus) eggs.

Although prairie-chickens are not suitable hosts for the obligate nest parasite, Brownheaded Cowbird (Molothrus ater), Svedarsky (1979) recorded two cowbird eggs in a prairiechicken nest containing 11 eggs in Minnesota. The nest was located in an unburned clump of bog birch (Betula pumila) and willow (Salix spp.) that was surrounded by burned brush prairie. 
Breeding-season phenology and site fidelity:

Male Greater Prairie-Chickens probably visit booming grounds throughout the year (although rarely in July and August), but regular attendance is most pronounced in the spring (particularly March, April, and May) and less so in late fall. Females begin visiting booming grounds in April. In Wisconsin, based on 6014 observation mornings in blinds, Hamerstrom and Hamerstrom (1973) reported 18 April as the day for peak hen visitation and 20 April for peak copulation. In Minnesota, at the northern edge of the species' range, Svedarsky (1983) reported 20 April for peak copulation. In Illinois, at the southern edge of the species' range, peak copulation was about one week earlier (Westemeier et al. 1998a). However, at a latitude similar to Illinois in Kansas, Robel (1970) observed peak copulation during 21-30 April.

About four days after the first copulation, hens begin laying one egg per day until reaching a clutch size of about 12 in Illinois (Westemeier, unpublished data) and Wisconsin (Hamerstrom 1939, $n=66$ nests). In Minnesota, the average clutch size of 26 nests was 13.2 (Svedarsky 1983). The incubation period ranges from 23-25 days (Gross 1930) and tends to be shorter for renesting attempts initiated later in the year (Svedarsky 1983). If nests are destroyed, hens may renest at least twice, but the clutch size will decrease in nests that are established later in the summer (Baker 1953, Robel and Ballard 1974, Svedarsky 1979).

Based on studies of marked birds, most territorial males ("regulars") that attend a given lek return day after day (Hamerstrom and Hamerstrom 1973). Furthermore, individual males tend to display on the same lek, or at least in the same general area, in subsequent years (Robel and Ballard 1974). Toepfer (1988) noted that about $82 \%$ of the males on a booming ground return from one year to the next, suggesting a high degree of site fidelity of males to a lek. Although females may develop a temporary "attachment” to a given lek and even to a particular male on the lek, they may visit other leks after a nest is destroyed and they begin renesting (Robel et al. 1970b, Svedarsky 1979). Females also may develop an attachment to a particular area where they have successfully nested in the past. Svedarsky (1988) documented two females that nested 4.6 and $29.8 \mathrm{~m}$ from their successful nests of the previous year. In Minnesota, Toepfer and E. Rosenquist (unpublished data) recorded a female that moved $12.8 \mathrm{~km}$ from the natal area and established nests in two consecutive years only $20 \mathrm{~m}$ apart. In the third year, she moved back to the natal area and nested for two more years within a 16.3-ha polygon.

\section{Species' response to management:}

Because Greater Prairie-Chickens depend on a variety of habitats to meet their annual needs, it is difficult to directly attribute population changes to specific management actions. This difficulty is compounded by interactions among habitat and climate, predation, and disease. Hence, this discussion also could be titled, "Management effects on habitats."

Fire.-Fire has been an evolutionary force that helped shape and maintain the prairie ecosystem for thousands of years. Higgins (1984) estimated a frequency of six lightning fires per year per $10,000 \mathrm{~km}^{2}$ in grasslands of eastern North Dakota. It is well documented that, for a variety of reasons, Native Americans set fires which were assuredly important in the development and maintenance of grasslands (Pyne 1985). The use of fire in managing prairies for the future remains equally important (Higgins et al. 1989a). Through the work of many researchers, prescribed burning has become an accepted vegetation management tool in grasslands (Bragg 1995). Of all grassland ecosystems in North America, tallgrass prairies seem to benefit most from fire. Kentucky bluegrass, an introduced cool-season species, can be nearly eliminated by spring burning in tallgrass prairie (Wright and Bailey 1982, Svedarsky et al. 1986). In Kansas, early (late winter, early spring) burning favors forbs; later (April, May) 
burning favors warm-season grasses (Hulbert 1986). Also, Hulbert (1986) found that more frequent burns favored grasses and that longer between-burn intervals favored forbs. A history of herbicide use (Clubine 2002) and current fire management practices have shifted many Kansas rangelands to grass-dominated habitats, probably to the detriment of Greater PrairieChickens (Robel, unpublished data). Howe (1994) cautioned that dormant-season burns and exclusion of grazers are human interventions that are favoring warm-season grasses and the reduction of plant species diversity that was maintained under a more sporadic burning and grazing regime. Fire helps control woody plants (Bragg and Hulbert 1976) and introduced Eurasian plants in tallgrass prairies and enhances growth of native prairie plants (Pemble et al. 1981). The absence of natural fire or prescribed burning has allowed woody vegetation to increase in many areas of the tallgrass prairie region. Burning of tallgrass prairie reduces litter cover and increases the number of reproductive grass shoots (Ehrenreich and Aikman 1963, Zedler and Loucks 1969, Hickey and Ensign 1983), and also results in a more rapid phenological development of young plants and an increase in flower production (Hadley and Keickhefer 1963). Bailey (1976) indicated that the control and reduction of wildfires resulted in an unprecedented increase in woody plants on Alberta grasslands that benefitted big-game populations but decreased the carrying capacity of rangeland for cattle. Bailey called for more prescribed burns to maintain grasslands and shrublands.

Burning of grasslands as a management tool has been shown to increase the nest density of Greater Prairie-Chickens (Westemeier 1973) and Sharp-tailed Grouse (Kirsch and Kruse 1973). In northwestern Minnesota, Svedarsky (1979) recommended rotational spring burning of preferred Greater Prairie-Chicken nesting habitats and fall burning of willow lowlands to create better brood habitat. However, this is not to suggest that burning in all situations is beneficial to Greater Prairie-Chicken management. In Kansas, extensive early-spring burning followed by heavy grazing has likely had a detrimental effect on populations because burning occurred during nesting and removed residual vegetation (Svedarsky et al. 2000).

Fire and grazing. - Early settlers of the Flint Hills of Kansas and northern Oklahoma observed that cattle selected forage from burned range more readily than unburned range and that steers gained weight faster on burned range than unburned range (Higgins et al. 1989b). More recently, the management practice of spring burning in the Flint Hills has been intensified (100\% of pastures) to improve forage value and utilization by livestock (Applegate and Horak 1999). Consequently, minimum nesting cover values for Greater Prairie-Chickens often are lacking in the Flint Hills of Kansas and Oklahoma due to a combination of annual spring burning and intensive grazing stimulated by the burning regime. "Good" range management is good for livestock production in this setting, but is detrimental to prairie grouse because there is "virtually no cover for spring nesting” (Clubine 2002:2). Clubine (2002) reported that patch burning and grazing, which involves rotationally burning a third of a parcel, offers ranchers an environmentally sensitive alternative which doesn't greatly diminish livestock yields. This could dramatically improve nesting conditions, however, by leaving as much as $2 / 3$ of the range unburned throughout the nesting season.

Grazing.-Vegetation quantity and structure have been the characteristics most often identified as the key habitat features affecting Greater Prairie-Chicken populations, especially as these features affect nesting and brood-rearing habitat (Svedarsky 1979, Westemeier 1980, Newell 1987). Prose (1985) identified four habitat components as important in determining the quality of Greater Prairie-Chicken nesting habitat: vegetation community, vegetation height (structure), disturbance factors, and open (treeless) areas. These same components presumably 
would be important for brood habitat. Grazing intensity and grazing systems directly affect the first three of these components.

The substantial increase in Greater Prairie-Chickens on the SNG between 1961 and 1987 was attributed mostly to changes in land management, primarily grazing practices (Kobriger et al. 1988). When the SNG was managed with season-long grazing, the population apparently was kept near the threshold of extinction. (Season-long grazing at low intensity is compatible with Greater Prairie-Chickens, but season-long grazing at high intensity is detrimental if it removes too much plant cover.) Pastures grazed season-long had VOR's $<15 \mathrm{~cm}$, the minimum necessary to provide adequate concealment cover for nesting or roosting (Manske et al. 1988). In the SNG, Newell et al. (1987) found that the majority (59\%) of nests were in three-pasture deferred systems. The deferred pasture of three-pasture systems was used by both brood and non-brood hens at a higher percentage of the time relative to other pastures. Nest success in pastures that were grazed season-long was very low; only one of seven nests successfully hatched.

Jensen (1992) reviewed seven studies from North Dakota and South Dakota, each of which evaluated grazing systems relative to providing adequate residual cover for grouse. Three of the seven studies recommended a rest- or deferred-rotation grazing system for Greater PrairieChickens (Kohn 1976, Rice and Carter 1982, Newell et al. 1988a). Two studies recommended twice-over rotation systems for Greater Prairie-Chickens (Manske et al. 1988, Sedivec and Barker 1989). One study recommended a season-long system, although it considered only Sharp-tailed Grouse (Mattise 1978). One study on Sharp-tailed Grouse was inconclusive (Grosz 1982). Kobriger et al. (1988) mentioned circumstantial evidence that declining Greater PrairieChicken populations were correlated with the initiation of rapid-rotation systems, which began in the early 1980’s. Given Newell's (1987) assessment that Greater Prairie-Chickens avoid areas with cattle, rapid-rotation systems have the potential to cause more brood movements, which could lead to greater predation. Jensen (1992) stated that evidence appears to support a threepasture, once-over, deferred system as being superior in providing residual cover. A common theme of these studies was the value of more residual cover to prairie grouse, at least in the Dakotas.

In South Dakota, Rice and Carter (1982) found that the height and density of ungrazed forage was influenced by both the grazing system and the stocking rate of individual allotments. Rest-rotation grazing involved idling some pastures each year, whereas deferred-rotation grazing involved grazing all pastures but delaying the initiation date. Winter pastures received little grazing pressure. When all range sites were combined, forage left ungrazed in a restrotation system was significantly greater than forage in deferred-rotation systems due to forage present in the ungrazed rest-rotation pasture. Although the hectares/AUM (Animal Unit Month) for the rest-rotation grazing system were lower than for any other grazing system tested, this system still left more forage ungrazed than the deferred-rotation system. Comparisons between systems showed that winter pastures produced 2.5 prairie-chicken nests and broods per 100 ha, whereas ungrazed rest-rotation pastures produced 2.3 nests and broods per 100 ha. Only 0.21 nests and broods per 100 ha were found on deferred-rotation systems. Rest-rotation grazing systems were substantially more beneficial to nesting and brooding grouse than were deferredrotation systems. Vegetative differences between rest- and deferred-rotation were due to grazing system design rather than AUM usage. Even when nest counts from grazed pastures of the restrotation system were included in the analysis, there were still significantly higher densities of grouse nests and broods than on deferred rotations. Of all grazing systems sampled, deferredrotation pastures were least preferred by nesting and brooding grouse. Although the stocking rate of the deferred-rotation systems was less than that for rest-rotation systems, the amount of 
ungrazed forage was lower. Grazing all pastures each year apparently leaves insufficient residual vegetation to meet minimum requirements for nesting and brooding grouse. Nesting use and success, as related to residual cover, were dependent on about $1121 \mathrm{~kg}$ of forage/ha being present no matter which grazing system was sampled. Rice and Carter (1982) recommended that grazing management within the Fort Pierre National Grassland should consist of a rest-rotation and winter-pasture grazing systems. An important point was that the rest-rotation system allowed rancher permittees to maintain livestock allocations, while allowing the production of over four times as many grouse as in the deferred-rotation system. They recommended that deferred-rotation grazing systems be discontinued on the Fort Pierre National Grassland because the minimum cover requirements for grouse of about $1121 \mathrm{~kg} / \mathrm{ha}$ of ungrazed forage cannot be attained using this system.

Grazing systems are not a panacea for solving all problems in grassland management, such as providing adequate residual cover for wildlife. Heady (1974) concluded that grazing systems have worked only when the managers quit overgrazing! After reviewing numerous studies, Van Poollen and Lacey (1979) concluded that adjustments in animal numbers have a greater effect on herbage production than do grazing systems. Wilson (1986) stated that "The total stocking intensity is the most important factor affecting rangeland productivity and stability." No grazing system will work to provide adequate residual vegetation if the stocking rate is too high. Leonard McDaniel (U.S. Fish and Wildlife Service, Valentine, Nebraska, pers. comm.) observed that when annual AUM's were reduced from 50,000 to 10,000 on the Valentine National Wildlife Refuge in Nebraska, there was a five-fold increase in booming male Greater Prairie-Chickens.

The timing of grazing and range management practices are important considerations as well. In the Flint Hills of Kansas (Applegate and Horak 1999) and Oklahoma (Horton and Wolfe 1999), there has been an increase in extensive spring burning to increase pasture utilization by livestock. Although this may be good for livestock production, it can significantly diminish the residual cover needed by hens and broods.

Cattle that graze in today's rangelands often are 30-40\% larger than the 454-kg standard used in most AUM allotments on public lands. Larger cattle require more forage, and therefore adjustments have to be made in order to use forage in proportion to the carrying capacity of the rangeland resource. In many if not all settings, it is impossible to optimize both livestock and Greater Prairie-Chicken production (as well as production of other desirable plant and animal populations).

Comparison of defoliation methods.-Burning, grazing, and mowing are all ways in which foliage may be removed, but plants and ecosystem functions may respond differently to these disturbances. Much of the response of a plant to defoliation depends upon its phenological stage and its evolutionary history. Manske (1995:2) noted that "the key to ecological management by effective defoliation is to match the timing of the defoliation to the phenological stage of growth that triggers the desired outcome." Heavy utilization of a plant during a critical period, whether by burning, grazing, or haying, can weaken it and make it more susceptible to competition. Burning at a particular time may damage actively growing plants while stimulating growth in other plants. These seasonal effects of burning are the rationale for using fire to control woody vegetation or Kentucky bluegrass (Svedarsky et al. 1986). Other factors also are affected by the type of defoliation. Burning, for instance, returns most of the nutrients to the ecosystem in relatively available forms, although small amounts of nutrients may be volatilized and lost. Burning also changes the physical and chemical factors of the ecosystem. Grazing does not remove as much of the herbage as does burning, and the defoliation during grazing is 
much more selective. Grazing returns some of the nutrients to the system, but many nutrients are lost when livestock are removed from the system. Changes in physical factors of the ecosystem are not as great with grazing but can be significant with trampling. Mowing removes herbage much like grazing, although without the selectivity. Mowing is not a natural form of ecological disturbance as are grazing and burning, but it does trigger some of the same responses. The greatest loss of nutrients by mowing occurs if the herbage is removed as hay. Grazing domestic livestock and wildlife is the natural way in which herbage is most often removed. Burning and mowing are both used as desirable methods to manipulate vegetation and to enhance grazing utilization. The main considerations for burning, grazing, and mowing are what, when, where, and at what intensity. All need to be considered in any management system.

Management frequency.-It is unclear at what point optimal nesting conditions occur after a new seeding or a disturbance (burning, grazing, mowing) of an established cover. In Illinois, Westemeier (unpublished data) documented low nest densities in (1) new meadows in their first full growing season, (2) meadows burned the previous August or March, and (3) fields hayed the previous year. Westemeier (1973, unpublished data) found more optimal prairiechicken nesting habitat in redtop and timothy seedings during the second to fourth growing seasons after the implementation of management techniques. These techniques were seeding, burning, no disturbance, mowing, or high mowing for seed, weed control, or structure enhancement. Kirsch (1974) suggested that prairie-chickens in North Dakota probably do not begin nesting in new seedings until 2-3 yr after appropriate residual cover has been established. Stands tend to lose their value as nesting habitat value between 5 and $7 \mathrm{yr}$ after seeding (Kirsch et al. 1973). Recent field studies by Toepfer (unpublished data) and co-workers indicated optimal nesting values of CRP plantings are attained in 2-4 yr, thus supporting Kirsch et al. (1973) and Westemeier (above). This could vary, however, depending on whether cool-season or warm-season seeding mixtures are used in CRP plantings. Kimmel et al. (1994) noted that cool-season grass plantings lose value as nesting cover sooner than warm-season grass plantings in terms of litter buildup and reduced VOR's, and that they should be rejuvenated more often (every 3-5 yr) than warm-season plantings.

The early spring availability of good residual cover is more important because it permits early nesting by experienced hens with the largest clutches and increases the total period available for nesting, which may accommodate one or two renesting attempts if needed (Kirsch 1969). In Minnesota, early nests have the potential to produce more offspring because of larger clutches than later nests, and broods also hatch before the rainy season (Svedarsky 1979). Furthermore, chicks that hatch earlier in the season will be older going into the fall and may have higher survival.

Cover varies with its ability to maintain structure after the compacting effects of winter snow. Cover dominated by Kentucky bluegrass, for example, tends to flatten more than native cover dominated by bunchgrasses such as little bluestem. Little bluestem is commonly mentioned as a principal plant species that occurs at Greater Prairie-Chicken nest sites. In Montana, the resistance of bunchgrasses to snow flattening was emphasized by Brown (1966) as important in Sharp-tailed Grouse management. Cover rejuvenation may be more critical in the north where substantial amounts of snow typically occur.

Habitat and predator relationships. - Prairie-chickens evolved with a variety of predators and developed various predator defense and avoidance strategies. The species expanded north of its original range, however, and is now exposed to Northern Goshawks (Accipiter gentilis) during the breeding season, with which they would have had limited evolutionary experience (F. Hamerstrom, Wisconsin Department of Natural Resources, 
Plainfield, Wisconsin, pers. comm.). Where Northern Goshawks and prairie-chickens co-occur in the prairie-chicken range (mostly Minnesota and Wisconsin), goshawks can be very effective predators of prairie-chickens, especially those that display in late winter or early spring. Thus, spring may be a period of high mortality for male prairie-chickens due to their greater exposure (and perhaps reduced alertness) on booming grounds and the possible presence of increased numbers of migratory raptors. Toepfer (1988) reported the following number of published accounts of predation per raptor species of prairie-chickens on booming grounds: ten Northern Goshawks, two Cooper's Hawks (Accipiter cooperii), one Red-tailed Hawk (Buteo jamicensis), one Great Horned Owl, and one Snowy Owl (Nyctea scandiaca). Svedarsky (unpublished data) observed a goshawk kill a prairie-chicken on a booming ground in northwestern Minnesota, and Burger (1988) had evidence of three Red-tailed Hawks killing prairie-chickens on booming grounds in Missouri.

Humans have modified the landscape so that prairie-chickens may have become more vulnerable to certain predators and numbers of certain predators may have increased. For example, trees along roads and drainage ditches, tree plantings in grasslands, and electrical power poles provide perching sites from which raptors can hunt. In the eastern portion of the prairie-chicken range, there is more woody vegetation along the prairie/forest transition zone. This woody vegetation is increasing due to wet cycles and the human control of prairie fires, which were a significant limiting factor of woody plant encroachment into the prairie before settlement (Bragg 1995). In Missouri (a forest/prairie transition state), Burger (1988) found that 38 of 63 radio-tagged prairie-chicken mortalities were due to raptors, particularly Great Horned Owls and Red-tailed Hawks. He found that females were most susceptible to predation during the nesting period, which results in the loss of both the hen and her potential production. Newell (1987) noted that most mortality of radio-marked hens at the SNG occurred in May.

Red foxes and skunks have been the most common mammalian predators of prairiechicken nests throughout most of the eastern range. Foxes generally have more impact than skunks because they commonly prey on the nesting hen. Over a 10-yr period, Svedarsky (1988) found December fox fur prices to be positively correlated with spring booming-ground counts two springs later. The conclusion was that trapping effort increased with the market incentive and that other potential predators were trapped as well (skunks, feral cats [Felis domesticus]). If trapping (and hunting) did, in fact, reduce mammalian predator numbers, it should have resulted in higher prairie-chicken production the next year and higher booming-ground counts the following year. This appeared to be the case. Further evidence for the high impact of foxes on large ground-nesting birds is that in areas where coyotes tend to displace foxes, nest success often increases. In North Dakota and South Dakota, Sovada et al. (1995) studied comparable areas except that some areas were dominated by red foxes and others by coyotes. Duck nests in coyote-dominated areas experienced nearly twice (32\%) the nesting success as those in foxdominated areas (17\%). The authors suggested that managing an area for coyotes rather than for foxes could be an effective method of increasing duck nest success. Svedarsky (1992) observed an increase in apparent nest success of larger ground-nesting birds (ducks and grouse) over a 2yr period in Minnesota. As coyotes apparently displaced foxes, nest success increased from $8.3 \%$ of 12 nests to $61.3 \%$ of 31 nests. Predator communities and densities may vary widely geographically and temporally over the range of prairie-chickens. In Kansas, Robel (unpublished data) noted that coyote densities were 0.39 per $\mathrm{km}^{2}$ in the $1950-60$ 's and 5.47 per $\mathrm{km}^{2}$ in 2001-2002. Coyotes seem to be increasing in eastern areas as well. In Minnesota, scentpost visitation indices suggested a doubling of coyotes in the agriculture and transition zones 
(which would include the prairie-chicken range) in the 1990's compared to the 1980's; red foxes increased through the 1980's and presently are declining (Dexter 1999).

Specific predator control often is not practical because of the cost and intensity required and because of public resistance, but there are habitat management alternatives. These include: 1) improving characteristics of nesting and brood cover, 2) reducing predator access trails in nesting and brood cover, 3) reducing potential mammalian predator den sites (e.g., rock piles, bulldozed piles of brush, and abandoned buildings), and 4) reducing potential raptor nesting sites and hunting perches. In Wisconsin, Peterson (1979) noted that neither Great Horned Owls or Red-tailed Hawks can hunt effectively without adequate perches. Because most of the raptors previously noted are "perch hunters," tree removal to reduce raptor hunting perches in prairiechicken habitat has become a recommended practice in Illinois (Westemeier, unpublished data), Minnesota (Svedarsky 1979; D. Trauba, Minnesota Department of Natural Resources, Watson, Minnesota, pers. comm.), Missouri (Burger 1988), and Wisconsin (Toepfer, unpublished data). Based on recent observations of bird survival and booming-ground use in apparent response to tree removal in Wisconsin, Toepfer (unpublished data) considered the reduction of open space via tree planting on grasslands to be one of the greatest impacts to prairie grouse habitat. Tree removal also reduces nesting sites for Great Horned Owls and Red-tailed Hawks, species that are uncommon in open prairie (R. K. Murphy, U.S. Fish and Wildlife Service, Kenmare, North Dakota, pers. comm.). Nesting sites for American Crows and Black-billed Magpies (nest predators in some areas) would be reduced by tree removal. Also, there is evidence that by increasing the block size of cover areas, nesting success may be improved. Ball et al. (1995) studied duck nesting in a heavily grazed area of Montana and recorded at least 48 broods per 100 breeding pairs, with variation in productivity attributed to grassland block size and red fox versus coyote domination. For Missouri, Burger (1988:100) recommended that "Management of greater acreages of nesting cover in larger tracts may reduce prairie-chicken nesting density and predator efficiency, thereby increasing nest success and female survival.”

Effects on insects. - Land management also can affect insect populations, which are important food sources for prairie-chickens. Clubine (2002:3) reported that "The Osage (Oklahoma) and Flint Hills (Kansas) have been assaulted with broadleaf herbicides over the last 50 years, often by aircraft. The effect has been near total elimination of forbs, most of which are...used by prairie insects which are critical food for newly hatched grassland birds...” In western North Dakota, Manske and Onsager (1996) reported that the migratory grasshopper (Melanoplus sanguinipes) was reduced by 66-75\% more on twice-over pastures than on seasonlong pastures. Apparently, the greater vegetation cover in the twice-over pasture reduced access for egg laying by grasshoppers. Bare, firm soil favored grasshoppers. Noetzel (1990:7) noted that "Grasshoppers usually prefer to oviposit in undisturbed (not tilled) sites such as roadsides, pasture, CRP, and weedy fallow. Weedy fallow is attractive to grasshopper egg laying, both because the weeds attract hoppers and the soil is firm.” Jones (1988) pointed out that haying may cause insects to concentrate near ground level, thus making them more readily available for foraging by prairie-chickens. The trade-off, however, is the greater exposure to predators. Svedarsky (1979) observed a female Northern Harrier (Circus cyaneus) depredate a 30-day-old, juvenile Greater Prairie-Chicken in alfalfa hayfield regrowth, $2.5 \mathrm{~cm}$ high. Burning significantly increased numbers of Hemiptera and Homoptera on a central Missouri prairie (Cancelado and Yonke 1970), and certain families of Coleoptera, Diptera, and Homoptera on a Minnesota prairie (Van Amburg et al. 1981). In Minnesota, Tester and Marshall (1961) found that burning increased Orthoptera, Coleoptera, and Homoptera. However, Halvorsen and Anderson (1979) found greater insect densities (770,395/ha) in unburned control plots than in burned plots 
$(44,460 / \mathrm{ha})$ in central Wisconsin. Hemiptera, Coleoptera, and Homoptera represented 70\% of insects in the authors' samples. Factors such as timing, intensity, fuel loads, and moisture all probably influence fire effects on insects; furthermore, different taxonomic groups may be affected differently.

Spatial arrangement of habitats. - In managing for the seasonal habitat needs of Greater Prairie-Chickens, one must consider how habitats should be arranged, how much of each habitat is needed during different seasons, and how to space habitats. Movement capabilities are clearly limited for broods, but movements at any time consume energy and potentially expose birds to predation. Hamerstrom and Hamerstrom (1973:28) perhaps summarized this relationship best: "With most of the known activities of the birds within a range of two-three miles [3.2-4.8 km], and almost all of them within five miles [8 km], it follows that management practices should also be close together so that all of the annual requirements of the birds can be met within small compass.” In central Wisconsin, Toepfer (1988) found that average annual home ranges of nine radio-tagged males and 12 females was $8.6 \mathrm{~km}^{2}$ and $28.8 \mathrm{~km}^{2}$, respectively. Precise effects of habitat type distribution on movements was unknown.

The concept of “ecological patterning” has guided Greater Prairie-Chicken management in Wisconsin since the 1950's (Hamerstrom et al. 1957). This concept proposed a network of grassland management units throughout private lands, yet it had not been thoroughly tested against an alternative of larger contiguous blocks of managed habitat. An important evaluation of these alternatives was conducted in Missouri (Ryan et al. 1998). The authors radio-tagged Greater Prairie-Chicken females in two areas. A 112- $\mathrm{km}^{2}$ "mosaic landscape" was composed of scattered prairie units that made up $11.9 \%$ of the landscape, with the remainder being in row crops and small grains. The "contiguous prairie landscape" was $52.5 \mathrm{~km}^{2}$ and composed of the same habitat types and amounts but configured differently. Native prairie composed $15.4 \%$ of this landscape, but $75 \%$ of that was contained within a $6.5-\mathrm{km}^{2}$ unit. This large block of prairie was managed by rotational burning and haying. Over a 27-yr period, the Greater PrairieChicken population had been relatively stable in the contiguous area but declined in the mosaic area. Apparent nest success was higher in the contiguous area during one of the $2 \mathrm{yr}$. Broods in the contiguous area had smaller home ranges and moved less than in the mosaic. Females nested more in agriculture areas of the mosaic area (more prone to nest destruction) compared to the contiguous area, where most nests occurred in the large prairie. At least in Missouri, Ryan et al. (1998) recommended managed contiguous tracts, because they were more productive for Greater Prairie-Chickens, over smaller, scattered prairie tracts within a landscape of privately owned agricultural land. The fact that the large prairie in the contiguous study area was rotationally managed was probably key to prairie-chickens being able to meet more of their habitat needs as opposed to no-disturbance management of the unit. Svedarsky (1979) suggested that the "ecological patterning” model should be applied directly to the relatively large managed grassland units (average size of 132.2 ha in 1979) within the Greater Prairie-Chicken range in Minnesota rather than the landscape itself. Another consideration is the optimal configuration of large contiguous habitat. Toepfer (pers. obs.) believes that the more linear configuration of habitat units within the primary Minnesota range (about $272 \mathrm{~km}$ by $19 \mathrm{~km}$ ) is better than a more equi-dimensional block.

Westemeier (1971) suggested that the number of displaying males on a booming ground provides an indication of habitat quality in that locality - a "biological indicator" of sorts. Thus, habitats around large booming grounds might be considered more ideal than habitats around small booming grounds. This rationale was used in a landscape ecology study in northwestern Minnesota in which Merrill et al. (1999) were able to establish some broad correlations between 
landscape characteristics surrounding booming grounds (less residential/farmsteads, smaller amounts of forests, greater amounts of CRP) compared to non-booming ground areas. Differences between traditional booming grounds (grounds with greater numbers of males) and temporary booming grounds were not clear because relationships between habitat conditions and booming-ground size can be difficult to establish unless careful assessments of land use - not simply habitat type - are made. For example, an extensive wildfire during the nesting peak could depress population recruitment, as measured by booming-ground counts the following spring, yet this event would not be reflected by simply classifying the habitat as "native grass" or "CRP."

\section{Management Recommendations:}

Ideally, Greater Prairie-Chickens should be managed on a broad landscape basis with a primary focus on nesting and brooding areas. In much of the current fragmented range, booming grounds have become the focus of management efforts because the majority of year-round locations are within $1.6 \mathrm{~km}$ of booming grounds (Anderson and Toepfer 1999, Westemeier and Gough 1999). Furthermore, Westemeier (1971:ii) suggested that "the number of cocks using a booming ground is a useful index of the quality of the neighboring habitat," and thus a general measure of the success of management actions as well as an indicator of population levels. The permanency of a given booming ground also would be an indication of the constancy of habitat quality in an area.

Manage residual nesting cover to have 100\% VOR at $25 \mathrm{~cm}$ and structure similar to managed smooth brome (Svedarsky 1979). Cover of this general structure should compose at least 2530\% of management areas (Westemeier 1971, Svedarsky and Van Amburg 1996, Westemeier and Gough 1999), should be near a similar percentage of brood habitats, and should be available early (March) to facilitate the greater productivity of early nests (Yeatter 1941, Baker 1953). Ensure that some litter is present, perhaps $5 \mathrm{~cm}$, but litter depths $>10 \mathrm{~cm}$, litter coverage $>25 \%$, and maximum vegetation heights $>50 \mathrm{~cm}$ are discouraged (McKee et al. 1998). Residual nesting cover is considered one of the key limiting factors throughout the range of the Greater PrairieChicken (Hamerstrom et al. 1957, Eng et al. 1988a, Vodehnal 1999) but may be more limiting in the western part of the range, where grazing is a more predominant land use than in the eastern part of the range. This may result from lower primary productivity in drier western areas, season-long grazing, or the practice of mowing lowlands and excessive spring burning to increase livestock utilization (Eng et al. 1988a, Applegate and Horak 1999, Horton and Wolfe 1999, Vodehnal 1999). Modifying these practices to provide the stated residual cover goals would benefit Greater Prairie-Chickens.

Rejuvenate nesting cover by rotational disturbance management every 3-5 yr, with prescribed burning being the most desirable disturbance (Kirsch et al. 1973, Westemeier and Buhnerkempe 1983, Toepfer 1988, Applegate and Horak 1999, Westemeier and Gough 1999). Manage coolseason grass plantings more frequently than warm-season grass plantings because cool-season grass plantings lose nesting cover values sooner as litter builds up (Kimmel et al. 1994).

Provide brood habitat that offers physical protection from weather and predators and is close to nesting cover; that facilitates chick movement at ground level; that supports abundant insects of 
the types that chicks eat; that provides forbs, especially legumes, for insect diversity and as a direct food source; and that provides openings for loafing and dusting (Svedarsky 1988). Brood habitats are generally different from nesting cover (Jones 1963, Burger 1988, Jones 1988, Toepfer 1988); the former requires some type of recent disturbance, and the latter generally needs to be undisturbed for one or two growing seasons before optimal use by nesting hens (Svedarsky 1988).

Minimize woody vegetation in priority management areas because its presence is associated with lower nest success (Svedarsky 1979, McKee et al. 1998) and increased raptor predation (Peterson 1979). Woody vegetation also adds to habitat fragmentation, which is generally detrimental to area-sensitive species (Sample and Mossman 1997, Mechlin et al. 1999).

In the North, provide agricultural crops for optimal winter survival of Greater Prairie-Chickens (Hamerstrom et al. 1957, Toepfer 1988, Vodehnal 1999, Westemeier and Gough 1999). In addition to their winter values, food plots are readily used, and perhaps very important, as spring feeding areas for adults and summer brood areas for hens and chicks (Hamerstrom 1963, Svedarsky 1979). Food plots or waste grain within management areas can minimize movements (and probably mortality) and should be accessible to prairie-chickens using optimal roosting habitat (Burger 1988, Rosenquist 1996). Sunflowers are considered a premium winter food in terms of preference and palatability, but corn, because of its standability through winter, and cereal grains are recommended as well (Church et al. 1989). In most areas, cropland should be present in a 25:75 ratio with grassland that provides nesting, brooding, and roosting cover (Applegate and Horak 1999, Westemeier and Gough 1999).

Maintain heavier cover (VOR $>30 \mathrm{~cm}$ ) for roosting, especially in lowlands, which are generally preferred (Ammann 1957, Svedarsky 1979, Toepfer 1988, Toepfer and Eng 1988). Roosting use of lowlands may be related to predator avoidance (Gratson 1988). In the northern regions, herbaceous forbs and/or some woody vegetation are important to promote an adequate accumulation of snow that is necessary for snow burrowing (Toepfer 1988, Rosenquist 1996). Cattail (Typha spp.) and bulrush (Scripus spp.) cover provides adequate roosting cover if snow becomes crusted and inaccessible for snow burrowing (Toepfer, unpublished data).

Place a high priority on managing habitats to reduce predation impacts on nesting and brood rearing, because high predation rates negate the value of adequate nesting and brooding cover (Svedarsky 1979; Robel, unpublished data). Actions include maintaining optimal residual cover for nesting (Duebbert 1969) and for brooding and roosting, reducing or preventing predator access trails in all cover types (Capel 1965, Kirsch 1969), reducing nesting or denning sites for predators, reducing raptor hunting perches, and increasing the block size of nesting cover (Johnson 1985, Burger 1988).

Provide all habitat elements within the home range of the birds. "With most of the known activities of the birds within a range of 2-3 miles [3.2-4.8 km], and almost all of them within 5 miles [ $8 \mathrm{~km}$ ], it follows that management practices should also be close together so that all of the annual requirements of the birds can be met within small compass" (Hamerstrom and Hamerstrom 1973:28). 
Table. Greater Prairie-Chicken habitat characteristics.

\begin{tabular}{|c|c|c|c|}
\hline Author(s) & Location(s) & Habitat(s) Studied* & Species-specific Habitat Characteristics \\
\hline Ammann 1957 & Michigan & $\begin{array}{l}\text { Idle tame, tame } \\
\text { hayland, woodland }\end{array}$ & $\begin{array}{l}\text { Of } 13 \text { nests, } 8 \text { were in hayfields, } 1 \text { in sweet clover } \\
\text { (Melilotus spp.), } 3 \text { in wildland openings, and } 1 \text { on an } \\
\text { airport; marshes and bogs were sought as roosting cover } \\
\text { when not too wet; } 10-25 \% \text { woody cover in habitat believed } \\
\text { to be ideal; } 86 \% \text { of booming grounds were within } 1.6 \mathrm{~km} \text { of } \\
\text { recently cultivated land }\end{array}$ \\
\hline Baker 1953 & Kansas & $\begin{array}{l}\text { Cropland, mixed-grass } \\
\text { hayland, mixed-grass } \\
\text { pasture, woodland }\end{array}$ & $\begin{array}{l}\text { Best range in eastern Kansas was mixture of cropland and } \\
\text { native bluestem (Andropogon gerardii, Schizachyrium } \\
\text { scoparium) grassland, the latter }>50 \% \text { of area and cropland } \\
\text { never }>1.6 \mathrm{~km} \text { from grass, and with blackjack oak (Quercus } \\
\text { marilandica) interspersed in some areas; spring burning of } \\
\text { native pasture was common, and the combination of } \\
\text { reduced residual cover through extensive burning and the } \\
\text { lack of winter food thought to be limiting factors to prairie- } \\
\text { chickens }\end{array}$ \\
\hline Blus and Walker 1966 & Nebraska & $\begin{array}{l}\text { Cropland, mixed-grass } \\
\text { pasture, tallgrass } \\
\text { hayland, tallgrass } \\
\text { pasture, tame hayland }\end{array}$ & $\begin{array}{l}\text { Nesting cover averaged } 12.7 \mathrm{~cm} \text {; principal species forming } \\
\text { nest canopies included sand lovegrass (Eragrostis } \\
\text { trichodes), little bluestem, and prairie sandreed } \\
\text { (Calamovilfa longifolia); occupied mainly the periphery of } \\
\text { the Sandhills, where tall- and mixed-grass prairies are } \\
\text { intermixed in the landscape with corn }\end{array}$ \\
\hline $\begin{array}{l}\text { Christisen and Krohn } \\
1980\end{array}$ & Missouri & $\begin{array}{l}\text { Cropland, tame } \\
\text { hayland, tame pasture, } \\
\text { woodland }\end{array}$ & $\begin{array}{l}\text { Tall fescue (Festuca elatior) believed to be marginal } \\
\text { grassland habitat due to its dense sod and sparse overstory; } \\
\text { at least } 25 \% \text { cover of perennial grass cover believed } \\
\text { necessary for population stability if a diverse species mix is } \\
\text { present and cropland is interspersed in the area }\end{array}$ \\
\hline Eng et al. $1988 b$ & North Dakota & Cropland, tallgrass & Lowland and midland communities received most of winter \\
\hline
\end{tabular}




\begin{tabular}{|c|c|c|c|}
\hline & & $\begin{array}{l}\text { hayland, tallgrass } \\
\text { pasture, tame hayland, } \\
\text { wet-meadow pasture }\end{array}$ & $\begin{array}{l}\text { and spring use by all radio-tagged hens as well as summer } \\
\text { use by brood hens }\end{array}$ \\
\hline Gross 1930 & Wisconsin & $\begin{array}{l}\text { Idle tame, idle wet } \\
\text { meadow, tame } \\
\text { hayland, wetland, } \\
\text { woodland }\end{array}$ & $\begin{array}{l}\text { Observed } 40 \text { nests in a variety of tame hayfields and near } \\
\text { woodland edges associated with farms; extensive wetlands } \\
\text { and grasslands considered requisite for overall habitat needs } \\
\text { along with grain farms for feeding areas }\end{array}$ \\
\hline Hamerstrom et al. 1957 & Wisconsin & $\begin{array}{l}\text { Cropland, idle tame, } \\
\text { tame hayland, tame } \\
\text { pasture, wetland, } \\
\text { woodland }\end{array}$ & $\begin{array}{l}\text { Emphasized need for space ( }<25 \% \text { wooded); most abundant } \\
\text { where there was greatest amount of perennial grassland } \\
\text { cover, especially Kentucky bluegrass (Poa pratensis); crops } \\
\text { (especially corn) were important for autumn and winter } \\
\text { food; “ecological patterning” (network of grassland } \\
\text { management units throughout private lands) of managed } \\
\text { and privately owned areas was important }\end{array}$ \\
\hline Horak 1985 & Kansas & $\begin{array}{l}\text { Burned mixed-grass } \\
\text { pasture, burned } \\
\text { tallgrass pasture, } \\
\text { cropland, mixed-grass } \\
\text { pasture, tallgrass } \\
\text { pasture }\end{array}$ & $\begin{array}{l}\text { Recommended } 70-80 \% \text { grass and } 10-20 \% \text { forbs as optimal } \\
\text { grassland composition, and habitat should be } 75 \% \\
\text { grassland and } 25 \% \text { cropland; prescribed fire best applied on } \\
\text { 4-yr rotation; large pastures were best because they } \\
\text { promoted a variety of grazing intensities with different } \\
\text { habitat uses }\end{array}$ \\
\hline Jones 1988 & Missouri & $\begin{array}{l}\text { Cropland, idle } \\
\text { tallgrass, tallgrass } \\
\text { hayland, tallgrass } \\
\text { pasture, tame hayland, } \\
\text { tame pasture, } \\
\text { woodland }\end{array}$ & $\begin{array}{l}\text { Large prairies were more effective than small prairies in } \\
\text { attracting females; disturbed areas, especially cropland, } \\
\text { were preferred by broods; } 72 \% \text { of } 37 \text { nests in prairie } \\
\text { occurred } 2 \text { yr after haying, and the remainder was in } \\
\text { various post-disturbance ages }\end{array}$ \\
\hline Kirsch et al. 1973 & North Dakota & $\begin{array}{l}\text { Cropland Adjustment } \\
\text { Program/Soil Bank: } \\
\text { idle tame, tallgrass } \\
\text { hayland, tallgrass }\end{array}$ & $\begin{array}{l}\text { Courtship areas always were found on or near } \geq 24 \text { ha of } \\
\text { retired cropland; none were found on hayland or heavily } \\
\text { grazed pasture without adjacent idle land; breeding bird } \\
\text { populations began to decline 5-7 yr after retired lands were }\end{array}$ \\
\hline
\end{tabular}




\begin{tabular}{|c|c|c|c|}
\hline & & $\begin{array}{l}\text { pasture, tame hayland, } \\
\text { tame pasture }\end{array}$ & seeded, suggesting the need for management \\
\hline Kobriger 1965 & Nebraska & $\begin{array}{l}\text { Cropland, mixed-grass } \\
\text { pasture, tallgrass } \\
\text { hayland, tame } \\
\text { hayland, wetland }\end{array}$ & $\begin{array}{l}\text { Use of grassland was associated with the presence of } \\
\text { cropland, especially corn }\end{array}$ \\
\hline Manske et al. 1988 & North Dakota & $\begin{array}{l}\text { Cropland, tallgrass } \\
\text { hayland, tallgrass } \\
\text { pasture, tame hayland, } \\
\text { wet-meadow pasture }\end{array}$ & $\begin{array}{l}\text { Rotational grazing systems were preferred by prairie grouse } \\
\text { over season-long systems for nesting and had spring visual } \\
\text { obstruction readings (VOR) }>1.5 \mathrm{dm}\end{array}$ \\
\hline Manske and Barker 1988 & North Dakota & $\begin{array}{l}\text { Cropland, tallgrass } \\
\text { pasture, tame hayland, } \\
\text { wet-meadow pasture }\end{array}$ & $\begin{array}{l}\text { Preferred hummocky sandhills during spring and summer; } \\
\text { preferred cropland areas of the deltaic plains and feeding } \\
\text { areas along railroad track in fall and winter; foraged in } \\
\text { alfalfa during summer }\end{array}$ \\
\hline Merill et al. 1999 & Minnesota & $\begin{array}{l}\text { Conservation Reserve } \\
\text { Program (CRP), } \\
\text { cropland, idle mixed- } \\
\text { grass, idle tallgrass, } \\
\text { idle tame, wetland, } \\
\text { woodland }\end{array}$ & $\begin{array}{l}\text { Traditional leks were surrounded by less forest and } \\
\text { cropland and by larger grassland patches than were } \\
\text { temporary leks }\end{array}$ \\
\hline Newell et al. $1988 b$ & North Dakota & $\begin{array}{l}\text { Cropland, tallgrass } \\
\text { hayland, tallgrass } \\
\text { pasture, tame hayland, } \\
\text { wet meadow }\end{array}$ & $\begin{array}{l}\text { Broods were located in native vegetation } 70.1 \% \text { of the time, } \\
\text { and, when there, they used lowlands, midlands, and uplands } \\
45.5,26.9 \text {, and } 23.2 \% \text { of the time, respectively; broods } \\
\text { showed an aversion to using areas when cattle were present }\end{array}$ \\
\hline Robel et al. 1970 & Kansas & $\begin{array}{l}\text { Burned mixed-grass } \\
\text { pasture, burned } \\
\text { tallgrass pasture, } \\
\text { cropland, mixed-grass } \\
\text { pasture, tallgrass }\end{array}$ & $\begin{array}{l}\text { Shallow range sites (transition between ridge sides and } \\
\text { tops) composed } 16-20 \% \text { of the study area yet accounted for } \\
\text { a majority of the habitat use in all seasons; these sites were } \\
\text { dominated by tall dropseed (Sporobolus asper), little } \\
\text { bluestem, and big bluestem (Andropogon gerardii); used }\end{array}$ \\
\hline
\end{tabular}




\begin{tabular}{|c|c|c|c|}
\hline & & pasture & sorghum fields extensively in winter \\
\hline Rosenquist 1996 & Minnesota & $\begin{array}{l}\text { Cropland, CRP: idle } \\
\text { tame; shrub carr }\end{array}$ & $\begin{array}{l}\text { In winter, agriculture and grass/forb habitats were used } \\
\text { about equally during the day, but for night roosting the } \\
\text { latter mostly were used; private CRP and agriculture lands } \\
\text { were used more than public lands; undisturbed vegetation } \\
\text { that was } 26-50 \mathrm{~cm} \text { tall was used mostly for roosting and } \\
\text { loafing, but vegetation } 0-8 \mathrm{~cm} \text { tall was used more for } \\
\text { feeding; combinations of grass and forbs were better than } \\
\text { grass-only for collecting snow preferred for snow roosting }\end{array}$ \\
\hline $\begin{array}{l}\text { Schroeder and Braun } \\
1992\end{array}$ & Colorado & $\begin{array}{l}\text { Cropland, idle, mixed- } \\
\text { grass pasture, sand- } \\
\text { sage grassland, } \\
\text { tallgrass pasture, } \\
\text { woodland }\end{array}$ & $\begin{array}{l}\text { Used cropland in winter and sand-sage (Andropogon hallii- } \\
\text { Artemesia), mixed-grass, and tallgrass species in late spring } \\
\text { and autumn more than estimated by availability; roosted in } \\
\text { mixed-grass and tallgrass vegetation in all seasons; nests } \\
\text { were typically in dense vegetation, averaging } 59 \mathrm{~cm} \text { in } \\
\text { height }\end{array}$ \\
\hline Toepfer 1988 & Wisconsin & $\begin{array}{l}\text { Burned tame, } \\
\text { cropland, idle tame, } \\
\text { idle wet meadow, } \\
\text { shrub carr, tame } \\
\text { pasture, wet-meadow } \\
\text { pasture, woodland }\end{array}$ & $\begin{array}{l}\text { Year-round grassland cover } 25-100 \mathrm{~cm} \text { tall composed } 65 \% \\
\text { of day locations and } 89 \% \text { of night locations; corn, } \\
\text { sunflowers, and soybeans were important winter foods; } \\
\text { taller }(>50 \mathrm{~cm}) \text { cover in grass/sedge or shrub wetlands were } \\
\text { used for winter roosting }\end{array}$ \\
\hline Toepfer and Eng 1988 & North Dakota & $\begin{array}{l}\text { Cropland, tallgrass } \\
\text { hayland, tallgrass } \\
\text { pasture, tame hayland, } \\
\text { wet-meadow pasture }\end{array}$ & $\begin{array}{l}\text { Agriculture composed } 41.7 \% \text { of all winter locations of } 22 \\
\text { radio-tagged birds; } 70.8 \% \text { of those were in harvested corn; } \\
\text { lowland grass and sedges accounted for } 64 \% \text { of night-roost } \\
\text { locations, mostly in areas }>25 \mathrm{~cm} \text { tall and undisturbed }\end{array}$ \\
\hline Westemeier 1971 & Wisconsin & $\begin{array}{l}\text { Cropland, idle, shrub } \\
\text { carr, tame hayland, } \\
\text { tame pasture, wet- } \\
\text { meadow pasture, } \\
\text { woodland }\end{array}$ & $\begin{array}{l}\text { Suggested minimum of } 50 \% \text { grassland, maximum of } 25 \% \\
\text { cropland, and } 25 \% \text { wet meadow, brush, and woodland for } \\
\text { good habitat }\end{array}$ \\
\hline
\end{tabular}




\begin{tabular}{|l|l|l|l|}
\hline $\begin{array}{l}\text { Westemeier 1973, 1985; } \\
\text { Westemeier and } \\
\text { Buhnerkempe 1983 }\end{array}$ & Illinois & $\begin{array}{l}\text { Burned tallgrass, idle } \\
\text { tallgrass, tallgrass } \\
\text { hayland, idle tame, } \\
\text { burned tame }\end{array}$ & $\begin{array}{l}\text { Cool-season exotic grasses averaged 2.5-4.5 nests per 10 ha } \\
\text { during a 29-yr study; prairie-chickens in high-mowed (>30 } \\
\text { cm) restored prairie grass stands showed greater nest } \\
\text { initiation and success than those in undisturbed prairie or } \\
\text { prairie hayed the previous year; overall densities averaged } \\
1.75 \text { nests per 10 ha in landscapes dominated by soybeans, } \\
\text { corn, and wheat; redtop (Agrostis stolonifera), timothy } \\
\text { (Phleum pratense), smooth brome (Bromus inermis), and } \\
\text { restored prairie grasses were managed by seed harvesting, } \\
\text { high mowing, burning, haying, and no-disturbance rotation } \\
\text { (disturbed in a rotation) }\end{array}$ \\
\hline
\end{tabular}

*In an effort to standardize terminology among studies, various descriptors were used to denote the management or type of habitat. "Idle" used as a modifier (e.g., idle tallgrass) denotes undisturbed or unmanaged (e.g., not burned, mowed, or grazed) areas. "Idle" by itself denotes unmanaged areas in which the plant species were not mentioned. Examples of "idle" habitats include weedy or fallow areas (e.g., oldfields), fencerows, grassed waterways, terraces, ditches, and road rights-of-way. "Tame" denotes introduced plant species (e.g., smooth brome [Bromus inermis]) that are not native to North American prairies. "Hayland" refers to any habitat that was mowed, regardless of whether the resulting cut vegetation was removed. "Burned" includes habitats that were burned intentionally or accidentally or those burned by natural forces (e.g., lightning). In situations where there are two or more descriptors (e.g., idle tame hayland), the first descriptor modifies the following descriptors. For example, idle tame hayland is habitat that is usually mowed annually but happened to be undisturbed during the year of the study. 


\section{LITERATURE CITED}

Ammann, G. A. 1957. The prairie grouse of Michigan. Federal Aid in Wildlife Research Project, Michigan 5-R, 37R, and 70-R. Game Division, Michigan Department of Conservation, Lansing, Michigan. 200 pages.

Anderson, R. K., and J. E. Toepfer. 1999. History, status and management of the Greater Prairie-Chicken in Wisconsin. Pages 39-58 in W. D. Svedarsky, R. H. Hier, and N. J. Silvy, editors. The Greater Prairie-Chicken: a national look. Miscellaneous Publication 99-1999. Agricultural Experiment Station, University of Minnesota, St. Paul, Minnesota.

Applegate, R. D., and G. J. Horak. 1999. History and status of the Greater Prairie-Chicken in Kansas. Pages 113-121 in W. D. Svedarsky, R. H. Hier, and N. J. Silvy, editors. The Greater Prairie-Chicken: a national look. Miscellaneous Publication 99-1999. Agricultural Experiment Station, University of Minnesota, St. Paul, Minnesota.

Bailey, A. W. 1976. Alberta’s rangeland resources. Rangeman’s Journal 3:44-46.

Baker, M. F. 1953. Prairie chickens of Kansas. Miscellaneous Publication Number 5. State Biological Survey of Kansas, Lawrence, Kansas. 68 pages.

Ball, I. J., R. L. Eng, and S. K. Ball. 1995. Population density and productivity of ducks on large grassland tracts in north central Montana. Wildlife Society Bulletin 23:767-773.

Bellinger, R. 2001. Loss of genetic variation in Greater Prairie-Chickens following a population bottleneck in Wisconsin. M.S. thesis. University of Wisconsin, Milwaukee, Wisconsin. 30 pages.

Blus, L. J., and J. A. Walker. 1966. Progress report on the prairie grouse nesting study in the Nebraska Sandhills. Nebraska Bird Review 34:23-30.

Bragg, T. B. 1995. The physical environment of Great Plains grasslands. Pages 49-81 in A. Joern and K. H. Keeler, editors. The changing prairie - the North American grassland. Oxford Press, New York, New York. 241 pages.

Bragg, T. B., and L. C. Hulbert. 1976. Woody plant invasion of unburned Kansas bluestem prairie. Journal of Range Management 29:19-24.

Brown, R. L. 1966. Response of sharptail breeding populations to annual changes in residual grassland cover. Proceedings of the Western Association of State Game and Fish Commissioners 46:219-222.

Buhnerkempe, J. E., W. R. Edwards, D. R. Vance, and R. L. Westemeier. 1984. Effects of residual vegetation on prairie-chicken nest placement and success. Wildlife Society Bulletin 12:382-386.

Burger, L. W. 1988. Movements, home range, and survival of female prairie chickens in relation to habitat pattern. M.S. thesis. University of Missouri, Columbia, Missouri. 108 pages. 
Cancelado, R., and T. R. Yonke. 1970. Effect of prairie burning on insect populations. Journal of the Kansas Entomological Society 43:274-281.

Capel, S. W. 1965. The relationship between grazing and predator activity in four types of waterfowl nesting cover. M.A. thesis. University of Missouri, Columbia, Missouri. 78 pages.

Carlson, C. E. 1942. The prairie chicken in Minnesota. Conservation Volunteer 4:45-49.

Christisen, D. M., and R. B. Krohn. 1980. Land use: a key to Greater Prairie-Chicken habitat in Missouri. Pages 55-58 in P. A. Vohs, editor. Proceedings of the Prairie Grouse Symposium. Oklahoma State University, Stillwater, Oklahoma.

Church, K. E., M. Heffron, and J. W. Parrish. 1989. Assimilated energy of winter foods by Greater Prairie-Chickens. Pages 10-11 in W. D. Svedarsky, editor. Abstracts of the Proceedings of the Eighteenth Prairie Grouse Technical Council Conference. University of Minnesota, Crookston, Minnesota.

Clubine, S. 2002. Editorial. Native warm-season grass newsletter. Volume 21, Number 3. Missouri Department of Conservation, Clinton, Missouri.

Dexter, M. H., compiler. 1999. Status of wildlife populations, fall 1999. Unpublished report. Section of Wildlife, Minnesota Department of Natural Resources, St. Paul, Minnesota. 169 pages.

Drobney, R. D., and R. D. Sparrowe. 1977. Land use relationships and movements of Greater Prairie-Chickens in Missouri. Transactions of the Missouri Academy of Science 1011:146-160.

Ehrenreich, J. H., and J. M. Aikman. 1963. Ecological study of the effect of certain management practices on native prairie in Iowa. Ecological Monographs 33:113-130.

Eng, R. L., J. E. Toepfer, and J. A. Newell. 1988a. Management of livestock to improve and maintain prairie habitat on the Sheyenne National Grasslands. Pages 55-57 in A. J. Bjugstad, technical coordinator. Prairie chickens on the Sheyenne National Grasslands. U.S. Department of Agriculture Forest Service General Technical Report RM-159. Rocky Mountain Forest and Range Experiment Station, Fort Collins, Colorado.

Eng, R. L., J. E. Toepfer, and J. Newell. 1988b. Management recommendations for prairiechickens on the Sheyenne National Grasslands, North Dakota, 1984-85. Phase III. Progress Report, Agreement Number 28-C2-204. Rocky Mountain Forest and Range Experiment Station, U.S. Department of Agriculture Forest Service, Fort Collins, Colorado, and Fish and Wildlife Program, Montana State University, Bozeman, Montana. 4 pages.

Grange, W. B. 1948. Wisconsin grouse problems. Publication No. 328-A. Wisconsin Conservation Department, Madison, Wisconsin. 318 pages.

Gratson, M. W. 1988. Spatial patterns, movements, and cover selection by Sharp-tailed Grouse. Pages 158-192 in A. T. Bergerud and M. W. Gratson, editors. Adaptive strategies and 
population ecology of northern grouse. University of Minnesota Press, Minneapolis, Minnesota.

Gross, A. O. 1928. The Heath Hen. Memoirs of the Boston Society of Natural History 6:491588.

Gross, A. O. 1930. Progress report of the Wisconsin prairie chicken investigation. Wisconsin Conservation Commission, Madison, Wisconsin. 112 pages.

Grosz, K. L. 1982. Sharp-tailed Grouse nesting and brood-rearing habitat in grazed and nongrazed treatments in south central North Dakota. M.S. thesis. North Dakota State University, Fargo, North Dakota. 72 pages.

Hadley, E. B., and B. J. Kieckhefer. 1963. Productivity of two prairie grasses in relation to fire frequency. Ecology 44:389-395.

Hagen, C. A., B. E. Jamison, R. J. Robel, and R. D. Applegate. 2002. Low parasitism rates of Lesser Prairie-Chickens by Ring-necked Pheasants in Kansas. Wilson Bulletin 114:522524.

Halfmann, D. H., J. E. Toepfer, and M. W. Blondin. 2001. Natal dispersal of Greater PrairieChickens in Wisconsin. Pages 32-33 in R. E. Horton, compiler. Proceedings of the Twenty-fourth Prairie Grouse Technical Conference. Woodward, Oklahoma.

Halvorsen, H. H., and R. K. Anderson. 1979. An evaluation of grassland management techniques in central Wisconsin. Pages 10-12 in R. K. Anderson, editor. Proceedings of the Thirteenth Prairie Grouse Technical Council Conference. University of Wisconsin, Stevens Point, Wisconsin.

Hamerstrom, F. N. 1939. A study of Wisconsin prairie chickens and Sharp-tailed Grouse. Wilson Bulletin 51:105-120.

Hamerstrom, F. N. 1963. Sharptail brood habitat in Wisconsin's northern pine barrens. Journal of Wildlife Management 27:793-802.

Hamerstrom, F. N., and F. Hamerstrom. 1949. Daily and seasonal movements of Wisconsin prairie chickens. Auk 16:312-337.

Hamerstrom, F. N., and F. Hamerstrom. 1963. The symposium in review. Journal of Wildlife Management 27:868-887.

Hamerstrom, F. N., and F. Hamerstrom. 1968. Water and the prairie chickens. Wisconsin Academy of Science 15:10-11.

Hamerstrom, F. N., Jr., and F. Hamerstrom. 1973. The prairie chicken in Wisconsin - highlights of a 22-year study of counts, behavior, movements, turnover, and habitat. Technical Bulletin 64. Wisconsin Department of Natural Resources, Madison, Wisconsin. 52 pages. 
Hamerstrom, F. N., Jr., F. Hopkins, and A. J. Rinzel. 1941. An experimental study of browse as winter diet for prairie chickens. Wilson Bulletin 53:185-195.

Hamerstrom, F. N., Jr., O. E. Mattson, and F. Hamerstrom. 1957. A guide to prairie chicken management. Technical Wildlife Bulletin Number 15. Wisconsin Conservation Department, Madison, Wisconsin. 128 pages.

Heady, H. F. 1974. Theory of seasonal grazing. Rangeman’s Journal 1:37-38.

Hickey, V. G., and R. D. Ensign. 1983. Kentucky bluegrass seed production characteristics as affected by residue management. Agronomy Journal 75:107-110.

Higgins, K. F. 1984. Lightning fires in grasslands in North Dakota and in pine-savanna lands in nearby South Dakota and Montana. Journal of Range Management 37:100-103.

Higgins, K. F., A. D. Kruse, and J. L. Piehl. 1989a. Prescribed burning guidelines in the northern Great Plains. Publication EC 760. South Dakota State University, Brookings, South Dakota. 36 pages.

Higgins, K. F., A. D. Kruse, and J. L. Piehl. 1989b. Effects of fire in the northern Great Plains. Publication EC 761. South Dakota State University, Brookings, South Dakota. 47 pages.

Hollifield, B. K., and R. W. Dimmick. 1995. Arthropod abundance relative to forest management practices benefitting Ruffed Grouse in the southern Appalachians. Wildlife Society Bulletin 23:756-764.

Horak, G. J. 1985. Kansas prairie chickens. Wildlife Bulletin No. 3. Kansas Fish and Game Commission, Pratt, Kansas. 65 pages.

Horak, G. J., and R. D. Applegate. 1998. Greater Prairie-Chicken management. Kansas School Naturalist 45:1-15.

Horton, R. E., and D. H. Wolfe. 1999. Status and management of the Greater Prairie-Chicken in Oklahoma. Pages 105-111 in W. D. Svedarsky, R. H. Hier, and N. J. Silvy, editors. The Greater Prairie-Chicken: a national look. Miscellaneous Publication 99-1999. Agricultural Experiment Station, University of Minnesota, St. Paul, Minnesota.

Howe, H. F. 1994. Managing species diversity in tallgrass prairie: assumptions and implications. Conservation Biology 8:691-704.

Hulbert, L. C. 1986. Fire effects on tallgrass prairie. Pages 138-142 in G. C. Clambey and R. H. Pemble, editors. The prairie: past, present, and future. Proceedings of the Ninth North American Prairie Conference. Tri-College Center for Environmental Studies, North Dakota State University, Fargo, North Dakota.

Jensen, W. F. 1992. Historical review of prairie chicken management on the Sheyenne National Grasslands. North Dakota Game and Fish Department, Bismarck, North Dakota. 155 pages. 
Johnson, R. G. 1985. Effects of prairie management practices on prairie birds. M.S. thesis. University of Wisconsin, Madison, Wisconsin. 53 pages.

Jones, D. P. 1988. Breeding ecology and habitat use of Greater Prairie-Chickens in relation to habitat pattern. M.S. thesis. University of Missouri, Columbia, Missouri. 90 pages.

Jones, R. E. 1963. Identification and analysis of Lesser and Greater prairie chicken habitat. Journal of Wildlife Management 27:757-778.

Kimmel, R. O., A. H. Berner, K. J. Haroldson, and R. J. Welsh. 1994. Cover quality of CRP grasslands. Wildlife Populations and Research Unit Report. Minnesota Department of Natural Resources, St. Paul, Minnesota. 5 pages.

Kirsch, L. M. 1969. Waterfowl production in relation to grazing. Journal of Wildlife Management 33:821-828.

Kirsch, L. M. 1974. Habitat management considerations for prairie chickens. Wildlife Society Bulletin 2:124-129.

Kirsch, L. M., A. T. Klett, and H. W. Miller. 1973. Land use and prairie grouse population relationships in North Dakota. Journal of Wildlife Management 37:449-453.

Kirsch, L. M., and A. D. Kruse. 1973. Prairie fires and wildlife. Proceedings of the Tall Timbers Fire Ecology Conference 12:289-303.

Kobriger, G. D. 1965. Status, movements, habitats, and foods of prairie grouse on a sandhills refuge. Journal of Wildlife Management 29:788-800.

Kobriger, G. D. D. P. Vollink, M. E. McNeill, and K. F. Higgins. 1988. Prairie chicken populations of the Sheyenne Delta in North Dakota. Pages 1-7 in A. J. Bjugstad, technical coordinator. Prairie chickens on the Sheyenne National Grasslands. U.S. Department of Agriculture Forest Service General Technical Report RM-159. Rocky Mountain Forest and Range Experiment Station, Fort Collins, Colorado.

Kohn, S. C. 1976. Sharp-tailed Grouse nesting and brooding habitat in southwestern North Dakota. M.S. thesis. South Dakota State University, Brookings, South Dakota. 123 pages.

Korschgen, L. J. 1962. Food habits of Greater Prairie-Chickens in Missouri. American Midland Naturalist 68:307-318.

Krapu, G. L. 1974. Feeding ecology of pintail hens during reproduction. Auk 91:278-290.

Lehmann, V. W. 1941. Attwater's Prairie-Chicken: its life history and management. U.S. Fish and Wildlife Service, North American Fauna 57. 63 pages.

Leopold, A. 1931. Report on a game survey of the north central states. American Game Association, Washington, D.C. 299 pages.

Manske, L. L. 1987. Winter activity of prairie grouse on the Sheyenne National Grasslands, North Dakota. Newsletter of the Minnesota Prairie Chicken Society 13:1-3. 
Manske, L. L. 1995. Adaptive tolerance mechanisms in grass plants. Range management report. North Dakota State University, Dickinson Research Extension Center, Dickinson, North Dakota. 3 pages.

Manske, L. L., and W. T. Barker. 1988. Habitat usage by prairie grouse on the Sheyenne National Grasslands. Pages 8-20 in A. J. Bjugstad, technical coordinator. Prairie chickens on the Sheyenne National Grasslands. U.S. Department of Agriculture Forest Service General Technical Report RM-159. Rocky Mountain Forest and Range Experiment Station, Fort Collins, Colorado.

Manske, L. L., W. T. Barker, and M. E. Biondini. 1988. Effects of grazing management treatment on grassland plant communities and prairie grouse habitat. Pages 58-72 in A. J. Bjugstad, technical coordinator. Prairie chickens on the Sheyenne National Grasslands. U.S. Department of Agriculture Forest Service General Technical Report RM-159. Rocky Mountain Forest and Range Experiment Station, Fort Collins, Colorado.

Manske, L. L. and J. A. Onsager. 1996. Grasshopper populations can be reduced by grazing management. DREC 96-1014. Dickinson Research Extension Center, North Dakota State University, Dickinson, North Dakota. 3 pages.

Marshall, W. H. 1963. Radio tracking of porcupines and Ruffed Grouse. Pages 173-178 in L. E. Slater, editor. Biotelemetry - the use of telemetry in animal behavior and physiology in relation to ecological problems. Pergamon Press, New York, New York.

Mattise, S. N. 1978. Effects of grazing systems on Sharp-tailed Grouse habitat. M.S. thesis. South Dakota State University, Brookings, South Dakota. 46 pages.

McKee, G. 1995. Ecology of Greater Prairie-Chickens in relation to habitat characteristics in southwestern Missouri. M.S. thesis. University of Missouri, Columbia, Missouri. 112 pages.

McKee, G., M. R. Ryan, and L. M. Mechlin. 1998. Predicting Greater Prairie-Chicken nest success from vegetation and landscape characteristics. Journal of Wildlife Management 62:314-321.

Mechlin, L. M., R. W. Cannon, and D. M. Christisen. 1999. Status and management of the Greater Prairie-Chicken in Missouri. Pages 129-142 in W. D. Svedarsky, R. H. Hier, and N. J. Silvy, editors. The Greater Prairie-Chicken: a national look. Miscellaneous Publication 99-1999. Agricultural Experiment Station, University of Minnesota, St. Paul, Minnesota.

Merrill, M. D., K. A. Chapman, K. A. Poiani, and B. Winter. 1999. Land-use patterns surrounding Greater Prairie-Chicken leks in northwestern Minnesota. Journal of Wildlife Management 63:189-198.

Mohler, L. L. 1952. Fall and winter habits of prairie chickens in southwest Nebraska. Journal of Wildlife Management 16:9-23.

Mussehl, T. W. 1963. Blue Grouse brood cover selection and land-use implications. Journal of Wildlife Management 27:547-555. 
National Geographic Society. 1999. Field guide to the birds of North America. National Geographic Society, New York, New York. 480 pages.

Newell, J. A. 1987. Nesting and brood-rearing ecology of the Greater Prairie-Chicken in the Sheyenne National Grasslands, North Dakota. M.S. thesis. Montana State University, Bozeman, Montana. 111 pages.

Newell, J. A., J. E. Toepfer, and R. L. Eng. 1988a. Nesting and brood-rearing ecology of the Greater Prairie-Chicken in the Sheyenne National Grasslands, North Dakota. Progress Report, Agreement Number 28-C2-204. Rocky Mountain Forest and Range Experiment Station, U.S. Department of Agriculture Forest Service, Fort Collins, Colorado, and Fish and Wildlife Program, Montana State University, Bozeman, Montana. 75 pages.

Newell, J. A., J. E. Toepfer, and M. A. Rumble. 1988b. Summer brood-rearing ecology of the Greater Prairie-Chicken on the Sheyenne National Grasslands. Pages 24-31 in A. J. Bjugstad, technical coordinator. Prairie chickens on the Sheyenne National Grasslands. U.S. Department of Agriculture Forest Service General Technical Report RM-159. Rocky Mountain Forest and Range Experiment Station, Fort Collins, Colorado.

Niemuth, N. D. 2000. Land use and vegetation associated with Greater Prairie-Chicken leks in an agricultural landscape. Journal of Wildlife Management 64:278-286.

Noetzel, D. M. 1990. Grasshopper management. Extension Bulletin Number AG-FO-3936. University of Minnesota, St. Paul, Minnesota. 10 pages.

Pemble, R. H., G. L. Van Amburg, and L. Mattson. 1981. Intraspecific variation in flowering activity following a spring burn. Pages 235-240 in R. L. Stuckey and K. J. Reese, editors. The prairie peninsula -- in the "shadow" of Transeau. Proceedings of the Sixth North American Prairie Conference, Columbus, Ohio.

Peterson, L. 1979. Ecology of Great Horned Owls and Red-tailed Hawks in southeastern Wisconsin. Technical Bulletin 111. Wisconsin Department of Natural Resources, Madison, Wisconsin. 63 pages.

Prose, B. L. 1985. Habitat suitability index models: Greater Prairie-Chicken (multiple levels of resolution). Biological Report Number 82 (10.102). U.S. Fish and Wildlife Service, Fort Collins, Colorado. 33 pages.

Pyne, S. J. 1986. These conflagrated prairies: a cultural fire history of the grasslands. Pages 131-137 in G. C. Clambey and R. H. Pemble, editors. Proceedings of the Ninth North American Prairie Conference. Tri-College Center for Environmental Studies, North Dakota State University, Fargo, North Dakota.

Rice, L. A., and A. V. Carter. 1982. Evaluation of South Dakota grassland management practices as they affect prairie chicken populations, 1974 - 1978. Completion Report No. 84-11, South Dakota Department of Game, Fish and Parks, Pierre, South Dakota. 25 pages.

Robel, R. J. 1966. Booming territory size and mating success of the Greater Prairie-Chicken (Tympanuchus cupido pinnatus). Animal Behaviour 14:328-331. 
Robel, R. J. 1970. Possible role of behavior in regulating Greater Prairie-Chicken populations. Journal of Wildlife Management 34:306-312.

Robel, R. J., and W. B. Ballard. 1974. Lek social organization and reproductive success in the Greater Prairie-Chicken. American Zoologist 14:121-128.

Robel, R. J., J. N. Briggs, J. J. Cebula, N. J. Silvy, C. E. Viers, and P. G. Watt. 1970b. Greater Prairie-Chicken ranges, movements, and habitat usage in Kansas. Journal of Wildlife Management 34:286-306.

Robel, R. J., J. N. Briggs, A. D. Dayton, and L. C. Hulbert. 1970a. Relationship between visual obstruction measurements and weight of grassland vegetation. Journal of Range Management 23:295-297.

Rosenquist, E. L. 1996. Winter aspects of prairie chicken ecology in northwest Minnesota. M.S. thesis. St. Cloud State University, St. Cloud, Minnesota. 72 pages.

Rosenquist, E. L., and J. E. Toepfer. 1995. A preliminary report on the winter ecology of the Greater Prairie-Chicken in northwest Minnesota. Pages 15-16 in G. D. Kobriger, editor. Proceedings of the Twenty-first Prairie Grouse Technical Council Conference. North Dakota Game and Fish Department, Dickinson, North Dakota.

Rumble, M. A., J. A. Newell, and J. E. Toepfer. 1988. Diets of Greater Prairie-Chickens on the Sheyenne National Grasslands. Pages 49-54 in A. J. Bjugstad, technical coordinator. Prairie chickens on the Sheyenne National Grasslands. U.S. Department of Agriculture Forest Service General Technical Report RM-159. Rocky Mountain Forest and Range Experiment Station, Fort Collins, Colorado.

Ryan, M. R., L. W. Burger, D. P. Jones, and A. P. Wywialowski. 1998. Breeding ecology of Greater Prairie-Chickens (Tympanuchus cupido) in relation to prairie landscape configuration. American Midland Naturalist 140:111-121.

Sample, D. W., and M. J. Mossman. 1997. Managing habitat for grassland birds: a guide for Wisconsin. Wisconsin Department of Natural Resources, Madison, Wisconsin. 154 pages.

Schmidt, F. J. W. 1936. Winter food of the Sharp-tailed Grouse and Pinnated Grouse in Wisconsin. Wilson Bulletin 48:186-203.

Schroeder, M. A., and C. E. Braun. 1992. Seasonal movement and habitat use by Greater Prairie-Chickens in northeastern Colorado. Special Report No. 68. Colorado Division of Wildlife, Fort Collins, Colorado. 44 pages.

Schroeder, M. A., and L. A. Robb. 1993. Greater Prairie-Chicken (Tympanuchus cupido). In A. Poole, P. Stettenheim, and F. Gill, editors. The birds of North America, No. 36. The Academy of Natural Sciences, Philadelphia, Pennsylvania; The American Ornithologists' Union, Washington, D.C.

Schwartz, C. W. 1945. The ecology of the prairie chicken in Missouri. University of Missouri Studies 20:1-99. 
Sedivec, K. K., and W. T. Barker. 1989. Effects of grazing systems on upland nesting birds in south central North Dakota. Phase III. North Dakota State University, Fargo, North Dakota. 125 pages.

Silvy, N. J. 1968. Movements, monthly ranges, reproductive behavior, and mortality of radiotagged Greater Prairie Chickens. M.S. thesis. Kansas State University, Manhattan, Kansas. 135 pages.

Silvy, N. J., C. P. Griffin, M. A. Lockwood, M. E. Morrow, and M. J. Peterson. 1999. The Attwater's Prairie-Chicken - a lesson in conservation biology research. Pages 153-162 in W. D. Svedarsky, R. H. Hier, and N. J. Silvy, editors. The Greater Prairie-Chicken: a national look. Miscellaneous Publication 99-1999. Agricultural Experiment Station, University of Minnesota, St. Paul, Minnesota.

Simpson, S. A., and T. E. Esker. 1997. Prairie Ridge State Natural Area habitat plan. Illinois Department of Natural Resources. Division of Natural Heritage, Springfield, Illinois. 80 pages.

Skinner, R. M. 1977. A comparison of grassland structure and prairie chicken use in Missouri. Page 12 in L. A. Rice, editor. Proceedings of the Twelfth Prairie Grouse Technical Council Conference. South Dakota Department Game, Fish, and Parks, Pierre, South Dakota.

Southwood, T. R. E., and D. J. Cross. 1969. The ecology of the partridge. III. Breeding success and the abundance of insects in natural habitats. Journal of Animal Ecology 38:497-509.

Sovada, M. A., A. B. Sargeant, and J. W. Grier. 1995. Differential effects of coyotes and red foxes on duck nest success. Journal of Wildlife Management 59:1-9.

Svedarsky, W. D. 1979. Spring and summer ecology of female Greater Prairie-Chickens in northwestern Minnesota. Ph.D. dissertation. University of North Dakota, Grand Forks, North Dakota. 166 pages.

Svedarsky, W. D. 1983. Reproductive chronology of Greater Prairie-Chickens in Minnesota and recommendations for censusing and nest searching. Prairie Naturalist 15:120-124.

Svedarsky, W. D. 1988. Reproductive ecology of female Greater Prairie-Chickens in Minnesota. Pages 193-267 in A. T. Bergerud and M. W. Gratson, editors. Adaptive strategies and population ecology of northern grouse. University of Minnesota Press, Minneapolis, Minnesota.

Svedarsky, W. D. 1992. Biological inventory of a multi-purpose flood control impoundment in northwest Minnesota and potentials for nongame and game bird management. Miscellaneous Publication. Northwest Research and Outreach Center, University of Minnesota, Crookston, Minnesota. 114 pages.

Svedarsky, W. D., P. E. Buckley, and T. A. Feiro. 1986. Effects of 13 years of annual burning on an aspen-prairie ecotone in northwestern Minnesota. Pages 118-122 in G. C. Clambey and R. H. Pemble, editors. Proceedings of the Ninth North American Prairie Conference, 
Moorhead, Minnesota. Tri-College Center for Environmental Studies, North Dakota State University, Fargo, North Dakota.

Svedarsky, W. D., and G. L. Van Amburg. 1996. Integrated management of the Greater PrairieChicken and livestock on the Sheyenne National Grasslands. Northwest Experiment Station, University of Minnesota, Crookston, Minnesota. 243 pages.

Svedarsky, W. D., R. L. Westemeier, R. J. Robel, S. Gough, and J. E. Toepfer. 2000. Status and management of the Greater Prairie-Chicken in North America. Wildlife Biology 6:277284.

Swanson, G. A., M. I. Meyer, and J. R. Serie. 1974. Feeding ecology of breeding Blue-winged Teals. Journal of Wildlife Management 38:396-407.

Tester, J. R., and W. H. Marshall. 1961. A study of certain plant and animal interactions on a native prairie in northwestern Minnesota. University of Minnesota Natural History Occasional Paper No. 8. 51 pages.

Toepfer, J. E. 1988. The ecology of the Greater Prairie-Chicken as related to reintroductions. Ph.D. dissertation. Montana State University, Bozeman, Montana. 533 pages.

Toepfer, J. E., and R. L. Eng. 1988. Winter ecology of the Greater Prairie-Chicken on the Sheyenne National Grasslands, North Dakota. Pages 32-48 in A. J. Bjugstad, technical coordinator. Prairie chickens on the Sheyenne National Grasslands. U.S. Department of Agriculture Forest Service General Technical Report RM-159.

Toepfer, J. E., R. L. Eng, and R. K. Anderson. 1990. Translocating prairie grouse - what have we learned? North American Wildlife and Natural Resources Conference 55:569-579.

Toney, T. E. 1980. Foods of prairie chickens on managed prairie. Pages 81-84 in P. A. Vohs, editor. Proceedings of the Prairie Grouse Symposium. Oklahoma State University, Stillwater, Oklahoma.

Van Amburg, G. L., J. A. Swaby, and R. H. Pemble. 1981. Response of arthropods to a spring burn of tall grass prairie in northwestern Minnesota. Pages 240-244 in R. L. Stuckey and K. J. Reese, editors. The prairie peninsula - in the "shadow" of Transeau. Proceedings of the Sixth North American Prairie Conference. Columbus, Ohio.

Van Poollen, H. W., and J. R. Lacey. 1979. Herbage response to grazing systems and stocking intensities. Journal of Range Management 32:250-253.

Viers, C. E. 1967. Home range and movements of the Greater Prairie-Chicken with notes on activities. M.S. thesis. Kansas State University, Manhattan, Kansas. 78 pages.

Vodehnal, W. L. 1999. Status and management of the Greater Prairie-Chicken in Nebraska. Pages 81-98 in W. D. Svedarsky, R. H. Hier, and N. J. Silvy, editors. The Greater Prairie-Chicken: a national look. Miscellaneous Publication 99-1999. Agricultural Experiment Station, University of Minnesota, St. Paul, Minnesota.

Westemeier, R. L. 1971. The history and ecology of prairie chickens in central Wisconsin. 
Research Bulletin No. 281. College of Agriculture and Life Sciences, University of Wisconsin, Madison, Wisconsin. 63 pages.

Westemeier, R. L. 1973. Prescribed burning in grassland management for prairie chickens in Illinois. Pages 317-338 in R. Komarek, editor. Proceedings of the Tall Timbers Fire Ecology Conference. Tall Timbers Research Station, Tallahassee, Florida.

Westemeier, R. L. 1980. Greater Prairie-Chicken status and management - 1968-1979. Pages 8-17 in P.A. Vohs, editor. Proceedings of Prairie Grouse Symposium. Oklahoma State University, Stillwater, Oklahoma.

Westemeier, R. L. 1985. Management plan for native prairie-chickens in Illinois. W-66-R. Illinois Natural History Survey, Effingham, Illinois.

Westemeier, R. L. 1988. Development of prairie pasture demonstration areas, Phase II. Illinois Natural History Survey Final Report (white paper). 22 pages.

Westemeier, R. L, J. D. Brawn, S. A. Simpson, T. L. Esker, R. W. Jansen, J. W. Walk, E. L. Kershner, J. L. Bouzat, and K. N. Paige. 1998b. Tracking the long-term decline and recovery of an isolated population. Science 282:1695-1698.

Westemeier, R. L., and J. E. Buhnerkempe. 1983. Responses of nesting wildlife to prairie grass management on prairie chicken sanctuaries in Illinois. Pages 39-46 in R. Brewer, editor. Proceedings of the Eighth North American Prairie Conference. Western Michigan University, Kalamazoo, Michigan.

Westemeier, R. L, J. E. Buhnerkempe, W. R. Edwards, J. D. Brawn, and S. A. Simpson. $1998 a$. Parasitism of Greater Prairie-Chicken nests by Ring-necked Pheasants. Journal of Wildlife Management 62:854-863.

Westemeier, R. L., and S. Gough. 1999. National outlook and conservation needs for Greater Prairie-Chickens. Pages 169-187 in W. D. Svedarsky, R. H. Hier, and N. J. Silvy, editors. The Greater Prairie-Chicken: a national look. Miscellaneous Publication 991999. Agricultural Experiment Station, University of Minnesota, St. Paul, Minnesota.

Westemeier, R. L., R. W. Jansen, and S. A. Simpson. 1995. Nest and brood habitat used by translocated Greater Prairie-Chickens in Illinois. Page 17 in G. D. Kobriger, editor. Proceedings of the Twenty-first Prairie Grouse Technical Council Conference. North Dakota Game and Fish Department, Dickinson, North Dakota.

Westemeier, R. L., and D. R. Vance. 1972. Responses of prairie chickens to habitat manipulations. Illinois Department of Conservation and Natural History Survey Research Letter 15:1-3.

Wilson, A. D. 1986. Principles of grazing management systems. Proceedings of the International Rangeland Congress 2:221-225.

Winter, M., D. H. Johnson, J. A. Dechant, T. M. Donovan, and W. D. Svedarsky. 1999. Evaluation of the Bird Conservation Area concept in the northern tallgrass prairie. Annual report: 1999. Northern Prairie Wildlife Research Center, U.S. Geological 
Survey, Jamestown, ND: Northern Prairie Wildlife Research Center Home Page. http://www.npwrc.usgs.gov/resource/2000/bcact/bcact.htm (Version 02MAR2000).

Winter, M., D. H. Johnson, J. A. Dechant, T. M. Donovan, and W. D. Svedarsky. 2001. Evaluation of the Bird Conservation Area concept in the northern tallgrass prairie. Annual report: 2001. Northern Prairie Wildlife Research Center, U.S. Geological Survey, Jamestown, ND: Northern Prairie Wildlife Research Center Home Page. http://www.npwrc.usgs.gov/resource/2002/bca2001/bca2001.htm (Version 04MAR2002).

Winter, M., D. H. Johnson, T. M. Donovan, and W. D. Svedarsky. 1998. Evaluation of the Bird Conservation Area concept in the northern tallgrass prairie. Annual report: 1998. Northern Prairie Wildlife Research Center, U.S. Geological Survey, Jamestown, ND: Northern Prairie Wildlife Research Center Home Page. http://www.npwrc.usgs.gov/resource/1999/bcarprt/bcarprt.htm (Version 18MAY99).

Winter, M., D. H. Johnson, T. M. Donovan, and W. D. Svedarsky. 2000. Evaluation of the Bird Conservation Area concept in the northern tallgrass prairie. Annual report: 2000. Northern Prairie Wildlife Research Center, U.S. Geological Survey, Jamestown, ND: Northern Prairie Wildlife Research Center Home Page. http://www.npwrc.usgs.gov/resource/2001/bca2000/bca2000.htm (Version 26JAN2001).

Wright, H. A., and A. W. Bailey. 1982. Fire ecology: United States and southern Canada. John Wiley and Sons, Inc., New York, New York. 501 pages.

Yeatter, R. E. 1943. The prairie chicken in Illinois. Illinois Natural History Survey Bulletin 22:377-416.

Zedler, J., and O. L. Loucks. 1969. Differential burning response of Poa pratensis fields and Andropogon scoparius prairies in central Wisconsin. American Midland Naturalist 81:341-352.

Zwickel, F. C., and J. F. Bendell. 1967. Early mortality and the regulation of numbers in Blue Grouse. Canadian Journal of Zoology 45:817-851. 